\title{
An Evaluation of Measures Regarding Road Traffic against the Urban Heat Island in the Tokyo Ward Area, Japan
}

\author{
Kohei Imai1 ${ }^{1}$ Kayoko Yamamoto ${ }^{2 *}$ \\ ${ }^{1}$ Fuji Xerox Co., Ltd., Yokohama, Japan \\ ${ }^{2}$ Graduate School of Information Systems, University of Electro-Communications, Tokyo, Japan \\ Email: ${ }^{*}$-yamamoto@is.uec.ac.jp
}

Received 31 July 2015; accepted 4 September 2015; published 7 September 2015

Copyright (C) 2015 by authors and Scientific Research Publishing Inc.

This work is licensed under the Creative Commons Attribution International License (CC BY).

http://creativecommons.org/licenses/by/4.0/

(c) (i) Open Access

\begin{abstract}
This study aims to evaluate measures against the Urban Heat Island (UHI) regarding artificial exhaust heat of road traffic using Geographic Information Systems (GIS) in the Tokyo Ward Area where the degree of UHI is particularly strong. We developed a GIS database that reflected road traffic conditions, and calculated the volume of artificial exhaust heat of road traffic to evaluate measures against the UHI. The findings of this study can be summarized in the following three points. 1) Artificial exhaust heat volume for moving targets was remarkably higher than that of stationary targets and, in particular, artificial exhaust heat volume was high on roads with remarkable numbers of vehicles and running speeds such as expressways and ring roads. 2) In UHIrelated policy for moving targets, the suppression of waste heat through choice of fuel burned, improvement of traffic flow by securing space for cyclists and pedestrians, development of bypasses, and upgrading signal control managed to reduce artificial exhaust heat volume, even though there were differences in degree of reduction. 3) In UHI-related policy for stationary targets, special road surfaces and the increase in efficiency of energy consumption equipment achieved a reduction ratio of around $30 \%$ in artificial exhaust heat volume, more than moving targets as well as making it possible to expect a reduction in artificial exhaust heat volume on a wide scale.
\end{abstract}

\section{Keywords}

Urban Heat Island (UHI), Road Traffic, Artificial Exhaust Heat, UHI-Related Policy, GIS

\section{Introduction}

Due to global warming in recent years, Urban Heat Islands (UHI) have become a serious problem for major ur${ }^{*}$ Corresponding author.

How to cite this paper: Imai, K. and Yamamoto, K. (2015) An Evaluation of Measures Regarding Road Traffic against the Urban Heat Island in the Tokyo Ward Area, Japan. Journal of Environmental Protection, 6, 957-975. 
ban areas in every country of the world. In the summer, UHI is a factor to enlarge the damages upon health such as heatstroke, discomfort in daily life, and torrential rains, by a rise in temperature in the daytime, and the increase of the tropical night. In the winter, UHI is also a factor to change ecosystem, for example, a change of the flowering time of plants, and wintering of creatures transmitting infectious diseases.

Japan's Inter-Ministry Coordination Committee to Mitigate Urban Heat Island developed the Outline of the Policy Framework to Reduce Urban Heat Island Effects in 2004. The Ministry of Economy, Trade and Industry (2007) [1] reported that Japan's energy consumption in the private consumer, transportation and industrial sectors increased by approximately 2.6, 2.1 and 1.0 times respectively from 1973 to 2005 . The Ministry of the Environment (2003) [2] also reported an increasing trend in artificial exhaust heat due to energy consumption in the Tokyo Ward Area, and suggested that the proportions of artificial exhaust heat were approximately 50\% buildings, $40 \%$ automobiles and $10 \%$ factories.

Mikami (2005) [3] suggested changes in urban structure and artificial exhaust heat as causes for UHI, while the Japanese Meteorological Agency (2007) [4] suggested changes in land use, the effects of buildings and the effects of artificial exhaust heat. Though the highest proportion of artificial exhaust heat is caused by buildings, measures to increase natural ground cover and greenery have already been implemented, and there are many examples of UHI research related to city green zones and increasing greenery for buildings and their grounds represented by Hirano et al. (2004) [5] and Hoyano (2005) [6]. However, the proportion of artificial exhaust heat caused by road traffic in the field of transportation, in particular automobiles, is high and despite this being one of the major causes of UHI, there has been little focus on this issue. Based on the above, this study targets the Tokyo Ward Area where UHI intensity is particularly high, using a Geographic Information System (GIS) [7], with the aim of evaluating UHI-related policies focusing on artificial exhaust heat from road traffic.

\section{Related Work}

The first study on UHI to be published in Japan was Tyson et al. (1973) [8], and the number of studies began to increase dramatically from around the year 2000. Based on the results of a review of prior research targeting the relationship between UHI and artificial exhaust heat in the same way as this study, the following 25 major studies were divided into 4 groups depending on their research targets.

1) Phenomenon/characteristics (3 studies): Mikami (2002) [9], Ashie et al. (2004) [10], Ishimaru (2004) [11].

2) Causes/mechanism (3 studies): Mikami (2005) [3], Ichinose (2009) [12], Terui et al. (2009) [13].

3) Effects/issues (12 studies): Mochida et al. (2001) [14], Narumi et al. (2002) [15], Yoshida et al. (2002) [16] [17], Kannari (2004) [18], Sugawara (2005) [19], Tamura et al. (2006) [20], Narumi (2006) [21], Ooka et al. (2006) [22], Shiraki et al. (2007, 2009) [23] [24], Narumi et al. (2009) [25].

4) Measures/effects (7 studies): Ota (2001) [26], Tamura et al. (2003, 2005, 2006) [27]-[30], Oba et al. (2006) [31], Kawamoto et al. (2008) [32].

As shown by the above prior research in related fields, though (3) Effects/issues have been most frequently studied, there have been few studies on the relationship between UHI and the artificial exhaust heat from road traffic. Only Ashie et al. (2004) [10] discussed the differences between sensible heat and latent heat, and calculated artificial exhaust heat output for road traffic in $500 \mathrm{~m}$ grid units in the Tokyo Ward Area using GIS to obtain an understanding of the output characteristics of artificial exhaust heat. Though Ashie et al. (2004) [10] conducted analysis in $500 \mathrm{~m}$ grid units, it did not specifically investigate to propose UHI mitigation, or a detailed understanding of artificial heat volume considering road traffic status.

Accordingly, this study refers the results of the above-mentioned prior research as a foundation, and highly effective GIS as a database development and information analysis tool to develop a digital map database reflecting the status of road traffic. Furthermore, using this, specific evaluation of UHI-related policy is conducted after calculating artificial exhaust heat volume from road traffic for each road unit using GIS.

\section{Evaluation Method}

\subsection{Evaluation Framework and Method}

This study began with a review of prior research to gather UHI-related policy with reference to artificial exhaust heat from road traffic in the Tokyo Ward Area, and organized this information focusing on the characteristics of each policy target. Effect functions were set in order to analyze the effects of UHI-related policy after imple- 
mentation, taking road traffic status into account, and road traffic status data and function coefficients used governmental open data, experiment results and estimated values.

Using the above method, if all data and research information is updated using future technology developments and advances in research, it will be possible to update and provide even more accurate information. In addition, though this study targeted the Tokyo Ward Area, as explained in detail in the next section, if it were possible to obtain the same kind of data and information, it would be possible to conduct evaluation by applying this evaluation method to other urban areas. Due to this, we can expect the evaluation method proposed in this study to be temporally and spatially general-purpose and duplicable.

Next, this study set initial functions prior to the implementation of each UHI-related policy and effect functions for post-policy implementation, suggested respective methods of calculating artificial exhaust heat volume before and after policy implementation using GIS, and used these to calculate artificial exhaust heat volume. Furthermore, by comparing artificial exhaust heat volume before and after the implementation of each UHIrelated policy, evaluation was conducted by investigating the effects of implementation of each policy. Though it should be noted that Ashie et al. (2004) [10] conducted analysis in 500 m grid units as mentioned above, this study used a digital base map that expresses roads in line format as detailed in the section below to add diverse data, and develop an integrated database to analyze and evaluate. By doing this, it was possible to calculate artificial exhaust heat volume by road unit and evaluate UHI-related policy, taking road traffic status characteristics into account.

\subsection{Study Area Description}

In this study, Tokyo Ward Area is selected as the study area. Tokyo Metropolis is the largest mega cities all over the world, and the Tokyo Ward Area is located in its center, as shown in Figure 1. The population of Japan is approximately 130 million people, and 51\% people live in the three major metropolitan areas such as Tokyo, Osaka-Kobe-Kyoto and Nagoya. Since 28\% people concentrate especially in Tokyo, the phenomenon is called as "Tokyo Centralization". Whereas, the depopulation happens in local areas, which is caused by the population movement to the major metropolitan areas, and the declining birthdate in the whole of Japan. According to the Tokyo Metropolitan Heat Island Mitigation Committee (2003) [33], recorded temperatures in the Tokyo Ward Area have risen by approximately $3^{\circ} \mathrm{C}$ in the past 100 years, and due to the fact that this rise is high in comparison with other large cities in Japan and other countries, it is understood that UHI intensity as urban warming is remarkably high in addition to the effects of global warming.

\subsection{GIS Database Development/Usage Process}

Figure 2 shows the development/usage process for the GIS database in this study. First of all, road data was developed in digital map format from 42,461 lines with numerical map 2500 (National Geospatial Framework)

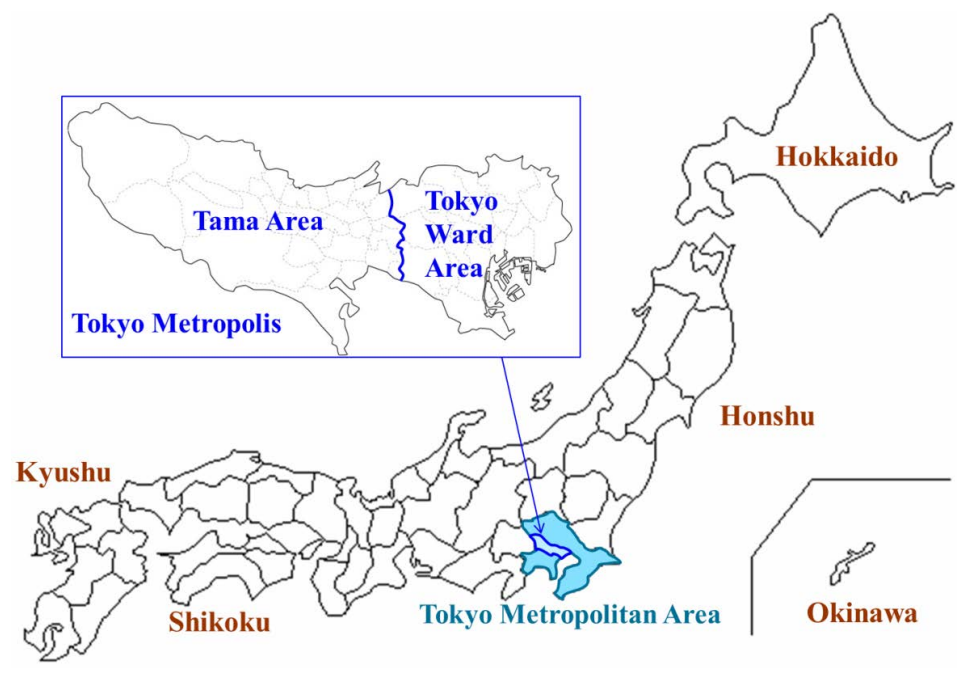

Figure 1. Location of study area. 


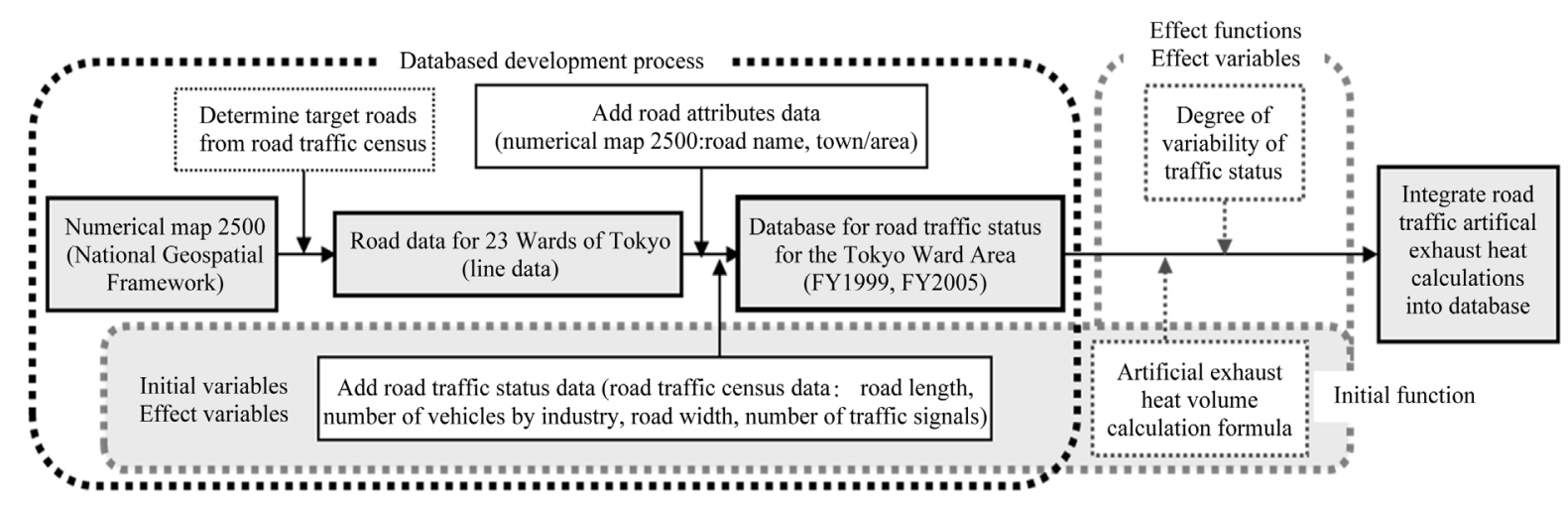

Figure 2. GIS database development/usage process.

[34]. Next, this data was added to/integrated with data relating to the road attributes and road traffic status in both FY 1999 and FY 2005 in road traffic census [35] and on numerical map 2500 to develop a database of road traffic status in the Tokyo Ward Area.

Furthermore, from the next section onwards, following the framework and method explained in the previous section, the volume of artificial exhaust heat before and after implementation of each UHI-related policy was calculated using GIS, and this data was also integrated into the road traffic status database. It should be noted that initial and effect variables for road traffic status data, effect variables for degree of variability of traffic status, and the artificial exhaust heat volume calculation formula included in initial and effect functions in Figure 2 are shown in Section 4. Section 5 shows the concrete artificial exhaust heat volume calculation method using GIS in a flow chart, and calculates artificial exhaust heat volume.

\section{Organization of UHI-Related Policy and Setting of Functions}

\subsection{The Relationships between the Organization of UHI-Related Policy and Functions}

All policies listed by the Ministry of the Environment (2003) [36], the Tokyo Metropolitan Heat Island Mitigation Committee (2003) [33], and the Ministry of Land, Infrastructure, Transport and Tourism (2007) [37] were researched, and the nine policies shown in Table 1 are the result of extracting only UHI-related policies that were implemented or under consideration for the mitigation of artificial exhaust heat from road traffic in the Tokyo Ward Area. Furthermore, the authors focused on the characteristics of each policy target, and divided to organize these into three groups: A. Transport framework/fuel, B. Road/road surface construction, and C. Road equipment. It should be noted that UHI-related policies No. 3, 4, 5, 7 and 8 aimed to improve running speed by alleviating and reducing traffic congestion during the day.

Though the effects of implementation of related policies are diverse, they do permit eventual effects that inhibit artificial exhaust heat (main effects). Accordingly, primary factors directly before achieving main effects were defined as supplementary effects, and the determinants of supplementary effects were determined as effect variables. Effect functions were set and calculations were made for artificial exhaust heat volume affected by the supplementary effects of each related policy using these effect variables. As shown in the previous section, initial functions were also set before the implementation of these policies in order to obtain an understanding of the implementation effects of each UHI-related policy.

It was possible to divide supplementary effects into four categories: improvements in fuel consumption, improvements in running speed, reduction in heat storage volume, and increase in efficiency of equipment. Furthermore, the targets of supplementary effects were divided into two groups: moving and stationary depending on whether the target is traffic flow data (number of vehicles, running speed) or traffic facility data (road length or width, number of traffic signals).

Using the above-mentioned method, it was possible to specify how effects are emphasized by the supplementary effects of each related policy, and to organize data categories in road traffic status data which is an effect variable and degree of variability of traffic status for each UHI-related policy. As moving targets were mainly affected by sensible heat and stationary targets by latent heat, it can be said that the categories in this study considers the effects of both sensible and latent heat. 
Table 1. UHI-related policy and effect variables.

\begin{tabular}{|c|c|c|c|c|c|c|c|c|c|c|}
\hline & \multirow{2}{*}{ Policy target } & \multirow{2}{*}{ Policy } & \multirow{2}{*}{ UHI-related policy } & \multirow{2}{*}{$\begin{array}{l}\text { Supplementary } \\
\text { effects }\end{array}$} & \multirow{2}{*}{$\begin{array}{l}\text { Effect } \\
\text { target }\end{array}$} & \multicolumn{5}{|c|}{$\begin{array}{c}\text { Effect variables } \\
\text { (road traffic status data/degree of variability in traffic status) }\end{array}$} \\
\hline & & & & & & $\begin{array}{l}\text { Road } \\
\text { length }\end{array}$ & $\begin{array}{l}\text { Number of } \\
\text { vehicles }\end{array}$ & $\begin{array}{l}\text { Running } \\
\text { speed }\end{array}$ & $\begin{array}{l}\text { Road } \\
\text { width }\end{array}$ & $\begin{array}{l}\text { Number of } \\
\text { traffic signals }\end{array}$ \\
\hline A. & $\begin{array}{l}\text { Transport } \\
\text { framework/fuel }\end{array}$ & No. 1 & $\begin{array}{l}\text { Spread of low-emission } \\
\text { vehicles (hybrid) }\end{array}$ & $\begin{array}{l}\text { Improvements in } \\
\text { fuel consumption }\end{array}$ & \multirow{4}{*}{ 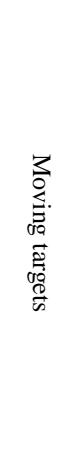 } & $\circ$ & $\begin{array}{l}\text { Diffusion } \\
\text { rate }\end{array}$ & ० & $\times$ & $x$ \\
\hline \multirow{4}{*}{ B. } & \multirow{4}{*}{$\begin{array}{l}\text { Road/road } \\
\text { surface } \\
\text { construction }\end{array}$} & No. 3 & $\begin{array}{l}\text { Improvement of traffic flow } \\
\text { by securing space for cyclists } \\
\text { and pedestrians }\end{array}$ & $\begin{array}{l}\text { Improvements in } \\
\text { running speed }\end{array}$ & & $\circ$ & o & $\begin{array}{l}\text { Progress } \\
\text { rate }\end{array}$ & $x$ & $x$ \\
\hline & & No. 4 & Development of bypasses & $\begin{array}{l}\text { Improvements in } \\
\text { running speed }\end{array}$ & & $\circ$ & $\circ$ & $\begin{array}{l}\text { Progress } \\
\text { rate }\end{array}$ & $\times$ & $x$ \\
\hline & & No. 5 & $\begin{array}{l}\text { Improvement of access roads } \\
\text { to airports and ports }\end{array}$ & $\begin{array}{l}\text { Improvements in } \\
\text { running speed }\end{array}$ & & $\circ$ & $\circ$ & $\begin{array}{l}\text { Progress } \\
\text { rate }\end{array}$ & $\times$ & $x$ \\
\hline & & No. 6 & $\begin{array}{l}\text { Special road surfaces } \\
\text { (water-holding surfaces) }\end{array}$ & $\begin{array}{l}\text { Reduction in heat } \\
\text { storage volume }\end{array}$ & \multirow{2}{*}{ 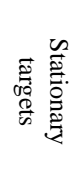 } & $\circ$ & $\times$ & $x$ & $\circ$ & $x$ \\
\hline \multirow{3}{*}{ C. } & \multirow{3}{*}{$\begin{array}{l}\text { Road } \\
\text { equipment }\end{array}$} & No. 7 & $\begin{array}{l}\text { Increase in efficiency of energy } \\
\text { consumption equipment } \\
\text { (changing signal lights to LED) }\end{array}$ & $\begin{array}{l}\text { Increase in } \\
\text { efficiency of } \\
\text { equipment }\end{array}$ & & $\times$ & $\times$ & $x$ & $\times$ & $\begin{array}{l}\text { Diffusion } \\
\text { rate }\end{array}$ \\
\hline & & No. 8 & Upgrading signal control & $\begin{array}{l}\text { Improvements in } \\
\text { running speed }\end{array}$ & \multirow{2}{*}{ 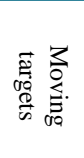 } & ० & ○ & $\begin{array}{l}\text { Progress } \\
\text { rate }\end{array}$ & $\times$ & $x$ \\
\hline & & No. 9 & Diffusion of ETC & $\begin{array}{l}\text { Improvements in } \\
\text { running speed }\end{array}$ & & ० & $\begin{array}{l}\text { Diffusion } \\
\text { rate }\end{array}$ & $\begin{array}{l}\text { Progress } \\
\text { rate }\end{array}$ & $\times$ & $x$ \\
\hline
\end{tabular}

1) The $\circ$ symbol in the table represents road traffic status data which is an effect target for supplementary effects in each UHI-related policy, and each value for road traffic status data and degree of variability in traffic status (diffusion and progress rates) marked with $\circ$ is used to calculate artificial exhaust heat volume. The $\times$ symbol represents road traffic status data which is not an effect target for supplementary effects in each UHI-related policy. 2) UHI-related policies No. 1 and No. 2 are both UHI policies related to automobiles. According to the Ministry of the Environment (2003), the Tokyo Metropolitan Heat Island Mitigation Committee (2003), and the Ministry of Land, Infrastructure, Transport and Tourism (2007), hybrid vehicles with two sources of power in the engine and in the motor, and driven using a combination of their respective benefits are defined as vehicles that can achieve both energy conservation and low emissions. Policy No. 1 targets only hybrid vehicles, whereas policy No. 2 targets vehicles that run on gasoline, excluding hybrid vehicles.

\subsection{Setting Initial Functions}

Table 2 provides an overview of initial functions, while Table 3 provides an overview of initial variables. A formula for calculating artificial exhaust heat volume in initial functions such as those in Table 2 was developed according to the two categories mentioned above, moving and stationary targets. Using this formula, a basic structure was formed to group effect functions calculating artificial exhaust heat volume after the implementation of each UHI-related policy. It should be noted that, as elements of effect functions were designated as effect variables, in the same way, elements of initial functions were designated as initial variables. Initial variables are: road traffic status data in road traffic census, waste heat coefficients by model and speed converted from the energy consumption coefficients by model and speed which are provided by the Ministry of Land, Infrastructure, Transport and Tourism/the Ministry of Environment [38], road surface waste heat coefficients in the results of Kanto Regional Development Bureau, the Ministry of Land, Infrastructure, Transport and Tourism project [39], and traffic signal waste heat coefficients converted to one day's worth of heat volume from electricity consumption by light bulb and LED from the National Police Agency [40].

Table 2 also shows each data category for road traffic status data used as initial variables, and these are also used in the same way in effect functions detailed in the next section. Road traffic census values were used in each of the above-mentioned categories, and values for numbers of cars, buses, and small and regular trucks were input by model and running speed values for both weekdays and holidays in FY2005 were firstly input. For the number of traffic signals, the number of intersections with traffic signals was calculated by dividing them into two types depending on the width of the road: main roads and minor roads, and the number of traffic signals was set at four as the average number found at a regular cross-shaped intersection and calculations were made. 
Table 2. Initial functions.

\begin{tabular}{ll}
\hline \multicolumn{1}{c}{ Initial target } & Initial function (Artificial exhaust heat volume calculated formula) $Q_{\alpha}, Q_{\beta}[\mathrm{J}]$ \\
\hline Moving target & $Q_{\alpha}=$ road length $\mathrm{L}[\mathrm{km}] \times$ number of vehicles by model M [number $] \times$ waste heat coefficient by model $/$ speed $C_{v}[\mathrm{~J} /(\mathrm{km} \cdot \mathrm{number})]$ \\
$\begin{array}{l}\text { Stationary } \\
\text { target }\end{array}$ & $\begin{array}{l}Q_{\beta}=\left(\text { road length } \mathrm{L}[\mathrm{km}] \times \operatorname{road} \text { width } \mathrm{W}[\mathrm{km}] \times \text { road surface waste heat coefficient } C_{l w}\left[\mathrm{~J} / \mathrm{km}^{2}\right]\right)+(\text { number of traffic signals S }[\text { number }] \\
\left.\times \text { traffic signal waste heat coefficient } C_{\mathrm{s}}[\mathrm{J} / \mathrm{number}]\right)\end{array}$ \\
\hline
\end{tabular}

Table 3. Outline of initial variables.

\begin{tabular}{|c|c|c|c|}
\hline Effect target & Initial variables & Explanation & Source \\
\hline $\begin{array}{l}\text { Moving } \\
\text { target }\end{array}$ & $\begin{array}{l}\text { Waste heat coefficient } \\
\text { by model speed } C_{V} \\
{[\mathrm{~J} /(\mathrm{km} \cdot \text { number })]}\end{array}$ & $\begin{array}{l}\text { Convert with waste heat by model } \\
4.1858[\mathrm{~kJ} / \mathrm{kcal}] \text { per source speed }\end{array}$ & $\begin{array}{l}\text { Ministry of Land, Infrastructure, Transport and Tourism/Ministry of the } \\
\text { Environment (2004) Survey of Heat Island Mitigation through Artificial } \\
\text { Exhaust Heat Control in Urban Areas } 2003 \\
\text { <http://www.mlit.go.jp/sogoseisaku/heat_island/05.pdf> }\end{array}$ \\
\hline
\end{tabular}

\begin{tabular}{|c|c|c|c|}
\hline & $\begin{array}{l}\text { Road surface waste } \\
\text { heat coefficient } \\
C_{R}\left[\mathrm{~J} / \mathrm{m}^{2}\right]\end{array}$ & $\begin{array}{l}\text { Asphalt road surface temperature } \\
\text { set at } 63\left[{ }^{\circ} \mathrm{C}\right][\text { Test value] ( } 1 \text { day’s } \\
\text { worth of waste heat volume } \\
6.24 \times 10^{4}\left[\mathrm{~kJ} / \mathrm{m}^{2}\right] \text { according to } \\
\text { the Stefan-Boltzmann Constant) }\end{array}$ & $\begin{array}{l}\text { Kanto Regional Development Bureau, Ministry of Land, Infrastructure, } \\
\text { Transport and Tourism (2004) The Challenge of alleviating the Heat } \\
\text { Island Phenomenon on Roads-Results of the Tokyo Environmental } \\
\text { Surface Project (press conference documents, 25th May, 2004) }\end{array}$ \\
\hline \multirow[t]{2}{*}{$\begin{array}{l}\text { Stationary } \\
\text { target }\end{array}$} & $\begin{array}{l}\text { Number of traffic } \\
\text { signals S [number] }\end{array}$ & $\begin{array}{l}\text { Number of traffic signals per } \\
\text { intersection set at } 4\end{array}$ & $\begin{array}{l}\text { Japan Society of Traffic Engineers Results of Responses to Enquiries to } \\
\text { Road Traffic Census Support Staff } 2005\end{array}$ \\
\hline & $\begin{array}{l}\text { Traffic signal waste } \\
\text { heat coefficient } \\
C_{L}[\mathrm{~J} / \text { number }]\end{array}$ & $\begin{array}{l}\text { Bulbs used determined as } 70 \mathrm{~W} \\
\text { [Document value] ( } 1 \text { day's worth } \\
\left.\text { of waste heat } 6.0 \times 10^{3}[\mathrm{~kJ} / \text { number }]\right)\end{array}$ & $\begin{array}{l}\text { National Police Agency Conversion of Traffic Signals to LED } \\
<\underline{\text { https://www.npa.go.jp/koutsuu/kisei/shisetu/led.pdf }>}\end{array}$ \\
\hline
\end{tabular}

\subsection{Setting Effect Functions}

Table 4 provides an overview of effect functions, while Table 5 provides an overview of effect variables. Effect functions such as those in Table 4 were composed using effect variables and in effect variables, there were functions for which degree of variability of traffic status was added to road traffic status data as shown in the previous section as a correction factor after the implementation of each UHI-related policy. Moreover, there were also functions for which heat waste coefficient by model/speed, road surface waste heat coefficient, and traffic signal waste heat coefficient were each converted respectively.

Degree of variability of traffic status effect variables was set as a correction factor in order to reflect the effects of the implementation of each UHI-related policy in each data category of road traffic status data. These are the actual changing values at the time of setting effect functions in order to calculate artificial exhaust heat volume after the implementation of each policy. If there are changes to the expected implementation effects of UHI-related policies, it is possible to recalculate artificial exhaust heat volume by re-setting this degree of variability for traffic status.

Moreover, waste heat coefficients by model/speed in initial functions were re-set in moving target UHI-related policies for No. 1, 2, 3, 4, 5, 8 and 9 as waste heat coefficients by model/speed in effect functions. This is because the policy target in UHI-related policies No. 1 and 2 is related to A. Transport framework/fuel, and there is potential for future change in goal values for waste heat volume, waste heat rate and rate of spread of target vehicles. This is because, in UHI-related policies No. 3, 4, 5, 8 and 9, corrected values for running speed in road traffic status data through improvement of degree of variability in traffic status at the time of composing effect functions are inherent as heat waste variables by model and speed. Furthermore, road surface waste heat coefficients in initial functions were reflected in the implementation effects of each policy as road surface heat waste variables in effect functions, and traffic signal waste heat variables in the same way in traffic signal waste heat coefficients, and each artificial exhaust heat volume was re-defined. UHI-related policy No. 3 was based on research results in the centre of Nagano City, and as a result of reviewing research such as data from governmental documents, experiment results and estimated values relating to the effect functions of the policies mentioned in Section 3.1, at present, this study determined that its own research target areas were the most appropriate. 
Table 4. Effect functions.

\begin{tabular}{|c|c|c|c|}
\hline Policy & UHI-related policy & Effect target & Effect function (Artificial heat exhaust volume calculation formula) $Q_{n}[\mathrm{~J}]$ \\
\hline No. 1 & $\begin{array}{l}\text { Spread of low-emission } \\
\text { vehicles (hybrid) }\end{array}$ & \multirow{4}{*}{ Moving targets } & $\begin{array}{l}\mathrm{Q}_{1}=\text { road length } \mathrm{L}[\mathrm{km}] \times\left[\left(\text { diffusion rate } \mathrm{d}_{1}[\%] \times \text { number of vehicles by model }\right.\right. \\
\left.\mathrm{M} \text { [number }] \times \text { waste heat variables by model } / \text { speed } X_{C v 1}[\mathrm{~J} /(\mathrm{km} \cdot \text { number })]\right)+ \\
\left\{\left(100 \text {-diffusion rate } d_{1}[\%]\right) \times \text { number of vehicles by model } \mathrm{M}[\text { number }] \times \text { waste }\right. \\
\left.\left.\text { heat coefficients by model } / \text { speed } C_{v}[\mathrm{~J} /(\mathrm{km} \cdot \text { number })]\right\}\right]\end{array}$ \\
\hline No. 2 & $\begin{array}{l}\text { Suppression of waste } \\
\text { heat through choice of } \\
\text { fuel burned (bioethanol) }\end{array}$ & & $\begin{array}{l}\mathrm{Q}_{2}=\text { road length } \mathrm{L}[\mathrm{km}] \times\left[\left(\text { diffusion rate } \mathrm{d}_{2}[\%] \times \text { number of vehicles by model }\right.\right. \\
\left.\mathrm{M} \text { [number }] \text { waste heat variables by model } / \text { speed } \mathrm{X}_{\mathrm{Cv} 2}[\mathrm{~J} /(\mathrm{km} \cdot \text { number })]\right)+ \\
\left\{\left(100 \text {-diffusion rate } d_{2}[\%]\right) \times \text { number of vehicles by model } \mathrm{M}[\text { number }] \times \text { waste }\right. \\
\left.\left.\text { heat coefficients by model } / \text { speed } C_{v}[\mathrm{~J} /(\mathrm{km} \cdot \text { number })]\right\}\right)\end{array}$ \\
\hline No. 3 & $\begin{array}{l}\text { Improvement of traffic } \\
\text { flow by securing space } \\
\text { for cyclists and pedestrians }\end{array}$ & & $\begin{array}{l}\mathrm{Q}_{3}=\text { road length } \mathrm{L}[\mathrm{km}] \times \text { noumber of vehicles by model } \mathrm{M}[\text { number }] \times \text { waste } \\
\text { heat variables by model } / \text { speed } X_{C v 3}[\mathrm{~J} /(\mathrm{km} \cdot \text { number })]\end{array}$ \\
\hline No. 5 & $\begin{array}{l}\text { Improvement of access } \\
\text { roads to airports and ports }\end{array}$ & & $\begin{array}{l}\left.\mathrm{Q}_{5}=\text { road length } \mathrm{L}[\mathrm{km}] \times \text { number of vehicles by model } \mathrm{M} \text { [number }\right] \times \text { waste } \\
\text { heat variables by model } / \text { speed } X_{C v 5}[\mathrm{~J} /(\mathrm{km} \cdot \text { number })]\end{array}$ \\
\hline No. 6 & $\begin{array}{l}\text { Special road surfaces } \\
\text { (water-holding surfaces) }\end{array}$ & \multirow[b]{2}{*}{ Stationary targets } & $\begin{array}{l}\mathrm{Q}_{6}=\operatorname{road} \text { length } \mathrm{L}[\mathrm{km}] \times \text { road width } \mathrm{W}[\mathrm{km}] \times \text { road surface waste heat variables } \\
X_{C l W}\left[\mathrm{~J} / \mathrm{km}^{2}\right]\end{array}$ \\
\hline No. 7 & $\begin{array}{l}\text { Increase in efficiency of } \\
\text { energy consumption equipment } \\
\text { (changing signal lights to LED) }\end{array}$ & & $\begin{array}{l}\mathrm{Q}_{7}=\text { number of traffic signals } \mathrm{S}[\text { number }] \times\left(\left\{\text { LEd diffusion rate } d_{7}[\%] \times \text { traffic }\right.\right. \\
\left.\text { signal waste heat variables } X_{C L}[\mathrm{~J} / \text { number }]\right\}+\left\{\left(100-\mathrm{LED} \text { diffusion rate } d_{7}[\%]\right)\right. \\
\left.\left.\times \text { traffic signal waste heat coefficients } C_{L}[\mathrm{~J} / \text { number }]\right\}\right)\end{array}$ \\
\hline No. 8 & Upgrading signal control & Moving targets & $\begin{array}{l}\left.\mathrm{Q}_{8}=\text { road length } \mathrm{L}[\mathrm{km}] \times \text { number of vehicles by model } \mathrm{M} \text { [number }\right] \times \text { waste heat } \\
\text { variables by model } / \text { speed } X_{C v 8}[\mathrm{~J} /(\mathrm{km} \cdot \text { number })]\end{array}$ \\
\hline
\end{tabular}

\section{Calculation of Artificial Exhaust Heat Volume Using GIS}

\subsection{Artificial Exhaust Heat Calculation Method}

Figure 3 shows the artificial exhaust heat volume calculation method using GIS in flow chart format. First of all, initial variables were set as heat waste coefficients by model and speed for moving targets, and as road surface heat waste coefficients and traffic signal waste heat coefficients for stationary targets in initial functions. Artificial exhaust heat volume was calculated before the implementation of UHI-related policies. Road traffic status data corrected with degree of variability in traffic status, waste heat variables by model and speed in moving targets, and road surface waste heat variables and traffic signal waste heat variables in stationary targets were set as effect variables in effect functions, and artificial exhaust heat volume was calculated after the implementation of UHI-related policies.

It should be noted that, as waste heat coefficients by model and speed differ in the daytime (9 am-8 pm) and the night-time (9 pm-8 am), artificial exhaust heat volume for moving targets was calculated for both daytime and night-time in addition to calculations for weekdays and holidays, and four types of vehicles in accordance with the categories in the road traffic census. However, as moving target UHI-related policies No. 3, 4, 5, 8 and 9 aimed to improve running speed by alleviating and reducing traffic congestion during the day, artificial exhaust heat volume after the implementation of these policies was calculated in the daytime. In addition, as stationary target artificial exhaust heat volume is calculated with one day's worth of waste heat volume, artificial exhaust heat volume after the implementation of stationary target UHI-related policies No. 6 and 7 was calculated by day. 
Table 5. Overview of effect variables.

\begin{tabular}{|c|c|c|c|}
\hline Policy & Effect variables & Explanation & Source \\
\hline \multirow[t]{2}{*}{ No.1 } & $\begin{array}{l}\text { Waste heat variables } \\
\text { by model/speed } X_{C v 1} \\
{[\mathrm{~J} /(\mathrm{k} \cdot \text { number })]}\end{array}$ & $\begin{array}{l}\text { Cars/buses: waste heat ratio of } 75 \% \\
\text { as hybrid vehicles [Assumed value] } \\
\text { small/regular trucks: waste heat ratio } \\
\text { of } 74 \% \text { as CNG trucks [Assumed value] }\end{array}$ & $\begin{array}{l}\text { Ministry of Land, Infrastructure, Transport and Tourism } \\
\text { (2005) Ranking by Vehicle Weight } \\
\text { < } \underline{\text { http://www.mlit.go.jp/kisha/kisha05/09/090223/02.pdf> }}\end{array}$ \\
\hline & $\begin{array}{l}\text { Diffusion rate } \\
d_{1}[\%]\end{array}$ & $\begin{array}{l}\text { Target vehicles are } 0.87 \% \text { of all vehicles } \\
\text { (figures from the year 2000) }\end{array}$ & $\begin{array}{l}\text { Japan Automobile Manufacturers Association (2001) Special Report } \\
\text { on the Development and Spread of Low-emission Vehicles } \\
\text { < } \underline{\text { http://www.jama.or.jp/lib/jamagazine/200109/01.html > }}\end{array}$ \\
\hline \multirow[b]{2}{*}{ No.2 } & $\begin{array}{l}\text { Waste heat variables } \\
\text { by model } / \text { speed } X_{C v 2} \\
{[\mathrm{~J} /(\mathrm{km} \cdot \text { number })]}\end{array}$ & $\begin{array}{l}60 \% \text { waste heat using E100 } \\
\text { [Assumed value] }\end{array}$ & $\begin{array}{l}\text { Council for Science, Technology and Innovation, Cabinet Office, Government } \\
\text { of Japan Roadmap and Diffusion Scenario for Environmental Energy Technology } \\
\text { < } \underline{\text { ttp://www8.cao.go.jp/cstp/siryo/haihu75/sanko2-1.pdf }>}\end{array}$ \\
\hline & $\begin{array}{l}\text { Diffusion rate } \\
d_{2}[\%]\end{array}$ & $\begin{array}{l}\text { Target vehicles are } 42 \% \text { of gasoline } \\
\text { vehicles (gasoline vehicle ratios/cars: } \\
88.7 \% \text {, buses: } 0.28 \% \text {, small/regular } \\
\text { rucks: } 24.6 \% \text { ) }\end{array}$ & $\begin{array}{l}\text { Daiwa Institute of Research (2007) New Industry Report 2007/summer: } \\
\text { Trends in Automobile Technology borne by the Next Generation } \\
\text { <http://www.dir.co.jp/souken/research/report/emg-inc/hitech/07060101hitech.pdf> } \\
\text { Ministry of Land, Infrastructure, Transport and Tourism, Policy Bureau } \\
\text { Information Management Division (2006) Outline of Traffic-related Energy } \\
\text { <http://www.mlit.go.jp/toukeijouhou/energy/h18_energy.pdf> }\end{array}$ \\
\hline No.3 & $\begin{array}{l}\text { Waste heat variables } \\
\text { by model } / \text { speed } X_{C v 3} \\
{[\mathrm{~J} /(\mathrm{km} \cdot \text { number })]}\end{array}$ & $\begin{array}{l}\text { Improve running speed for all vehicles } \\
\text { by } 10 \% \text { except on national/urban } \\
\text { expressways [Simulation value] }\end{array}$ & $\begin{array}{l}\text { Yuichi Harumoto (2006) Understanding of the Current Status of Urban } \\
\text { Traffic and Bicycle Use in Nagano City } \\
\text { < } \underline{\text { http://taklab12.shinshu-u.ac.jp/contents/subjects/Others/pdf/B4_harumoto.pdf> }}\end{array}$ \\
\hline No.4 & $\begin{array}{l}\text { Waste heat variables } \\
\text { by model } / \text { speed } X_{C v 4} \\
{[\mathrm{~J} /(\mathrm{km} \cdot \text { numner })]}\end{array}$ & $\begin{array}{l}\text { For roads (congested roads) with running } \\
\text { speed of } 20[\mathrm{~km} / \mathrm{h}] \text { or less, running speed } \\
\text { is set at } 21[\mathrm{~km} / \mathrm{h}] \text { as a congestion solution } \\
\text { value [Assumed value] }\end{array}$ & $\begin{array}{l}\text { Inter-Ministry Coordination Committee to Mitigate Urban Heat Island (2004) } \\
\text { Outline of the Policy Framework to Reduce Urban Heat Island Effects } \\
\text { <http://www.env.go.jp/air/life/heat_island/taikou.pdf> } \\
\text { Ministry of Land, Infrastructure, Transport and Tourism Kanto Regional } \\
\text { Development Bureau Alleviating Traffic Congestion } \\
\text { < } \underline{\text { http://www.ktr.mlit.go.jp/3kanjo/efficacy/traffic_jam.htm> }}\end{array}$ \\
\hline No.5 & $\begin{array}{l}\text { Waste heat variables } \\
\text { by model/peed } X_{C v 5} \\
{[\mathrm{~J} /(\mathrm{km} \cdot \text { number })]}\end{array}$ & $\begin{array}{l}\text { For roads with running speed of } 20 \text { [km/h] } \\
\text { or less, such as coastal roads (national } \\
\text { highways } 14 \text { and } 357 \text {, coastal expressways) } \\
\text { and the Yokohama-Haneda Airport urban } \\
\text { expressway, running speed is increased by } \\
13 \% \text { as a congestion alleviation value } \\
\text { [Current congestion alleviation value] }\end{array}$ & $\begin{array}{l}\text { Tokyo Metropolitan Government (2000) Basic Aviation Policy } \\
\text { (enhancement/strengthening of access to } 4 \text { airports) } \\
\text { <http://www.toshiseibi.metro.tokyo.jp/kanko/ksk/03-4.pdf> } \\
\text { Ministry of the Environment (2007) (Annex) State of Progress of Specific } \\
\text { Policies recorded in the Outline of the Policy Framework (July, 2007 } \\
\text { Ministry of the Environment press conference documents) } \\
\text { <http://www.env.go.jp/press/file_view.php?serial=9863\&hou_id=8588> }\end{array}$ \\
\hline No.6 & $\begin{array}{l}\text { Road surface waste } \\
\text { heat variable } X_{C R} \\
{\left[\mathrm{~J} / \mathrm{km}^{2}\right]}\end{array}$ & $\begin{array}{l}\text { Set at } 40^{\circ} \mathrm{C} \text { using water-holding surfaces } \\
\text { [Test value] }(1 \text { day's worth of waste heat } \\
\text { volume } 4.70 \times 10^{4}\left[\mathrm{~kJ} / \mathrm{m}^{2}\right] \text { according to } \\
\text { the Stefan-Boltzmann Constant) }\end{array}$ & $\begin{array}{l}\text { Ministry of Land, Infrastructure, Transport and Tourism, Kanto Regional } \\
\text { Development Bureau (2004) The Challenge of alleviating the Heat Island } \\
\text { Phenomenon on Roads-Results of the Tokyo Environmental Surface Project } \\
\text { (press conference documents, 25th May, 2004) }\end{array}$ \\
\hline \multirow[b]{2}{*}{ No.7 } & $\begin{array}{l}\text { Traffic signal waste } \\
\text { heat variables } X_{C L} \\
\text { [J/number] }\end{array}$ & $\begin{array}{l}\text { Set at } 15 \mathrm{~W} \text { using LED [Document value] } \\
\text { (1 day's worth of waste heat volume } \\
\left.1.3 \times 10^{3}[\mathrm{~kJ} / \text { number }]\right)\end{array}$ & $\begin{array}{l}\text { National Police Agency Conversion of Traffic Signals to LED } \\
\text { < } \underline{\text { ttps://www.npa.go.jp/koutsuu/kisei/shisetu/led.pdf }>}\end{array}$ \\
\hline & $\begin{array}{l}\text { LED diffusion } \\
\text { rate } d_{7}[\%]\end{array}$ & $\begin{array}{l}\text { LED diffusion rate was set at } 39.4 \% \\
\text { (Rate of use of LED in vehicles in } \\
\text { Tokyo) (Number of traffic signals } \\
\text { at } 1 \text { intersection was set at } 4 \text { ) }\end{array}$ & $\begin{array}{l}\text { National Police Agency Number of Instances of Maintenance in Traffic } \\
\text { Signals by Prefecture } \\
\text { < https://www.npa.go.jp/koutsuu/kisei/institut/kazu.pdf }>\end{array}$ \\
\hline No.8 & $\begin{array}{l}\text { Waste heat variables } \\
\text { by model } / \text { speed } X_{C v 8} \\
{[\mathrm{~J} /(\mathrm{km} \cdot \text { number })]}\end{array}$ & $\begin{array}{l}\text { Improve running speed for all vehicles } \\
\text { by } 10 \% \text { excluding national expressways, } \\
\text { urban expressways and minor roads with } \\
\text { no traffic signals [ } 2007 \text { Goal Values for } \\
\text { the Policy Framework to Reduce Urban } \\
\text { Heat Island Effects] }\end{array}$ & $\begin{array}{l}\text { Ministry of the Environment (2007) (Annex) State of Progress of Specific } \\
\text { Policies recorded in the Outline of the Policy Framework (July, } 2007 \text { Ministry } \\
\text { of the Environment press conference documents) } \\
\text { < } \underline{\text { http://www.env.go.jp/press/file_view.php?serial=9863\&hou_id=8588> }}\end{array}$ \\
\hline \multirow[t]{2}{*}{ No.9 } & $\begin{array}{l}\text { Waste heat variables } \\
\text { by model/speed } X_{C v 9} \\
{[\mathrm{~J} /(\mathrm{km} \cdot \text { number })]}\end{array}$ & $\begin{array}{l}\text { For national and urban expressways which } \\
\text { are roads (congested roads) with running } \\
\text { speed of } 20[\mathrm{~km} / \mathrm{h}] \text { or less, running speed } \\
\text { is increased to } 13 \% \text { as a congestion } \\
\text { alleviation value [Current congestion } \\
\text { alleviation value] }\end{array}$ & $\begin{array}{l}\text { Ministry of the Environment (2007) (Annex) State of Progress of } \\
\text { Specific Policies recorded in the Outline of the Policy Framework } \\
\text { (July, } 2007 \text { Ministry of the Environment press conference documents) } \\
\text { < } \underline{\text { http://www.env.go.jp/press/file_view.php?serial=9863\&hou_id=8588> }}\end{array}$ \\
\hline & $\begin{array}{l}\text { Diffusion } \\
\text { rate } d_{9}[\%]\end{array}$ & $\begin{array}{l}75.8 \% \text { of all vehicles are target vehicles } \\
\text { (national figure as of December, 2008) }\end{array}$ & $\begin{array}{l}\text { Ministry of Land, Infrastructure, Transport and Tourism (2008) Status } \\
\text { of Usage of ETC (bulletin) (as of 18th December, 2008) } \\
\text { < } \underline{\text { http://www.mlit.go.jp/road/yuryo/riyou.pdf }>}\end{array}$ \\
\hline
\end{tabular}




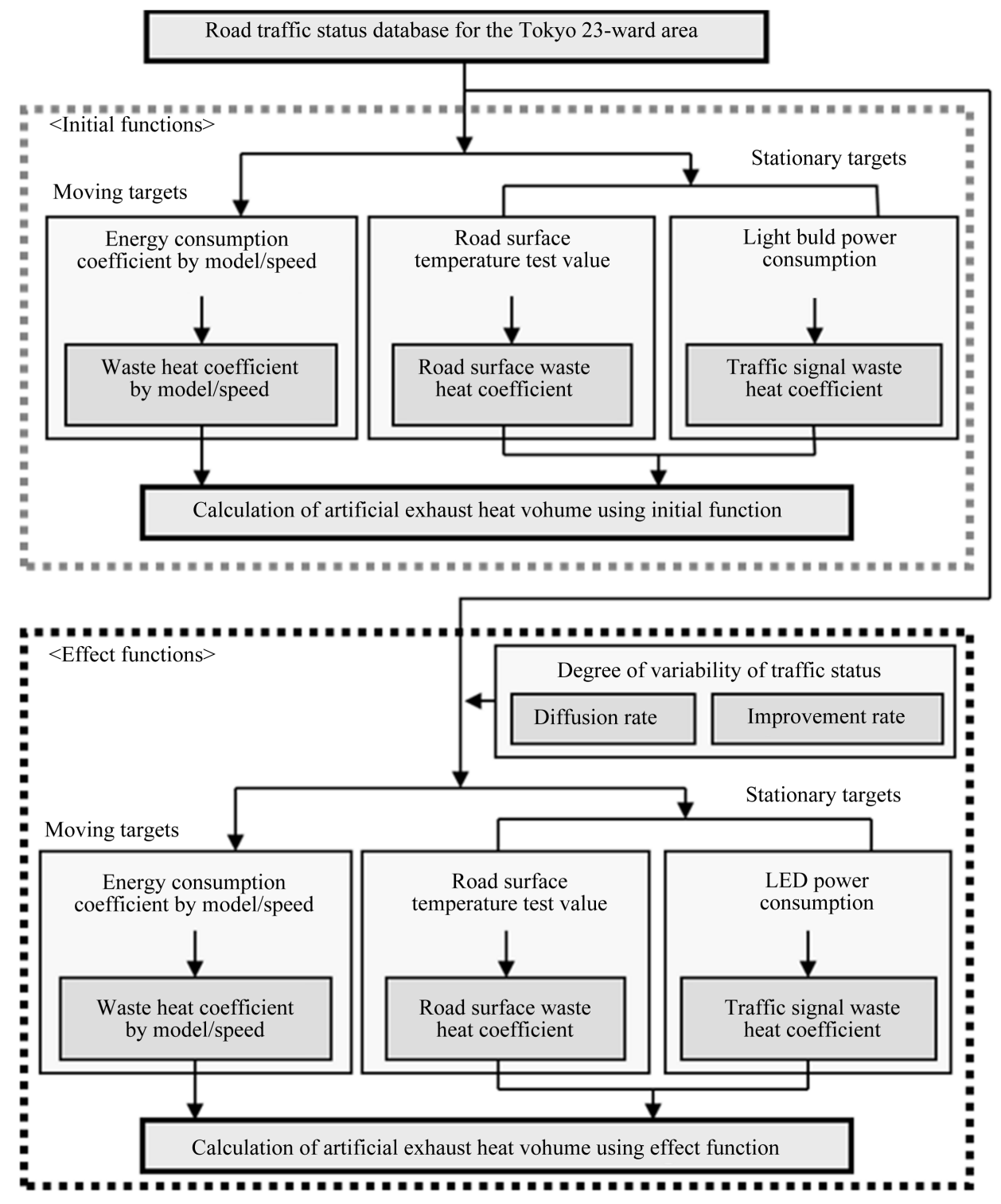

Figure 3. Calculation method for artificial exhaust heat volume using GIS.

\subsection{Results of Calculations of Artificial Exhaust Heat Volume}

Using the calculation method shown in the previous section, artificial exhaust heat volume was calculated for both moving and stationary targets. Table 6 shows artificial exhaust heat volume for moving targets which was remarkably high in comparison to that of stationary targets. Figure 4 shows the statuses of artificial exhaust heat volume for moving targets, classifying into daytime and night-time in addition to weekdays and holidays. Figure 4 depicts the weekday daytime status where artificial exhaust heat is at its highest. In addition, as artificial exhaust heat volume was high for all vehicles, regardless of the time, on the same roads with remarkable vehicles numbers and running speed such as expressways and ring roads, Table 6 shows artificial exhaust heat volume for all these roads.

Figure 5 shows the statuses of artificial exhaust heat volume for stationary targets such as road surface and traffic lights. It should be noted that artificial exhaust heat volume for stationary targets was 1,336,070,000 kJ from road surface and 6,939,200,000 kJ from traffic lights for one day on all roads in the Tokyo Ward Area. Total artificial exhaust heat volume for these stationary targets was not more than around $1.3 \%$ of total artificial exhaust heat volume for both daytime and night-time for moving targets on both weekdays and holidays. 
Table 6. Results of calculation of artificial exhaust heat volume for moving targets by model (\%, top value: daytime, bottom value: night-time).

\begin{tabular}{|c|c|c|c|c|c|c|c|c|c|c|c|}
\hline \multirow{2}{*}{ Area } & \multirow{2}{*}{ Road } & \multicolumn{2}{|c|}{ Car } & \multicolumn{2}{|c|}{ Bus } & \multicolumn{2}{|c|}{ Small truck } & \multicolumn{2}{|c|}{ Regular truck } & \multicolumn{2}{|c|}{ Total for each road $(10,000 \mathrm{~kJ})$} \\
\hline & & Weekday & Holiday & Weekday & Holiday & Weekday & Holiday & Weekday & Holiday & Weekday & Holiday \\
\hline \multirow{4}{*}{ Centre } & Metropolitan & 40.0 & 44.3 & 3.1 & 3.2 & 11.0 & 11.5 & 46.0 & 41.0 & $18,525.5$ & $19,263.0$ \\
\hline & $\begin{array}{l}\text { Expressway No. } 4 \\
\text { (Shinjuku) }\end{array}$ & 40.0 & 42.5 & 3.1 & 3.1 & 11.0 & 11.9 & 45.9 & 42.4 & $17,175.6$ & $18,596.3$ \\
\hline & Metropolitan & 34.2 & 33.9 & 2.2 & 2.3 & 8.6 & 8.6 & 55.0 & 55.2 & $27,567.4$ & $23,664.4$ \\
\hline & $\begin{array}{l}\text { Expressway } \\
\text { (ring road) }\end{array}$ & 34.2 & 33.9 & 2.2 & 2.3 & 8.6 & 8.7 & 55.0 & 55.2 & $25,553.7$ & $21,929.0$ \\
\hline \multirow{2}{*}{ North } & Metropolitan & 30.4 & 24.1 & 1.5 & 1.3 & 8.1 & 7.2 & 60.0 & 67.3 & $65,718.4$ & $54,310.9$ \\
\hline & $\begin{array}{l}\text { Expressway No. } 5 \\
\text { (Ikebukuro) }\end{array}$ & 29.1 & 26.2 & 1.4 & 1.5 & 7.7 & 7.9 & 61.8 & 64.5 & $63,803.3$ & $46,328.1$ \\
\hline \multirow{4}{*}{ East } & Metropolitan & 42.4 & 42.4 & 0.9 & 0.9 & 9.5 & 9.7 & 47.3 & 47.0 & $15,004.4$ & $11,796.6$ \\
\hline & Expressway No. 7 & 42.4 & 42.5 & 0.9 & 0.9 & 9.5 & 9.7 & 47.3 & 46.9 & $13,905.7$ & $10,945.2$ \\
\hline & Metropolitan & 24.2 & 23.6 & 3.7 & 3.9 & 7.8 & 8.0 & 64.3 & 64.5 & $8,692.3$ & $6,431.9$ \\
\hline & Expressway No. 9 & 24.2 & 23.7 & 3.7 & 3.9 & 7.8 & 8.0 & 64.3 & 64.3 & $8,057.0$ & $5,965.7$ \\
\hline \multirow{2}{*}{ West } & & 44.3 & 43.2 & 3.8 & 4.1 & 9.9 & 10.2 & 42.0 & 42.5 & $5,016.0$ & $3,225.7$ \\
\hline & Cnuo Expressway & 44.3 & 43.3 & 3.8 & 4.1 & 9.9 & 10.2 & 42.0 & 42.4 & $4,650.6$ & 2,992.6 \\
\hline \multirow{2}{*}{ Northeast } & Metropolitan & 23.6 & 23.1 & 1.8 & 1.8 & 6.9 & 6.9 & 67.7 & 68.3 & $25,894.5$ & $24,716.8$ \\
\hline & Expressway No. 6 & 23.6 & 23.1 & 1.8 & 1.8 & 6.9 & 6.9 & 67.7 & 68.2 & $24,004.1$ & $22,912.8$ \\
\hline \multirow{4}{*}{ Southeast } & $\begin{array}{l}\text { Metropolitan Road } \\
\text { No. } 482\end{array}$ & 41.3 & 41.3 & 3.9 & 3.9 & 15.5 & 15.5 & 39.3 & 39.3 & $43,851.8$ & $43,851.8$ \\
\hline & (Daiba/Ome) & 41.3 & 41.3 & 3.9 & 3.9 & 15.5 & 15.5 & 39.3 & 39.3 & $40,656.0$ & $40,656.0$ \\
\hline & Metropolitan & 17.7 & 17.2 & 3.3 & 3.3 & 6.5 & 6.5 & 72.5 & 72.3 & $17,210.4$ & $17,075.9$ \\
\hline & $\begin{array}{l}\text { Expressway } \\
\text { (coastal route) }\end{array}$ & 17.7 & 17.4 & 3.3 & 3.3 & 6.5 & 6.5 & 72.5 & 72.3 & $15,944.7$ & $15,810.1$ \\
\hline \multirow{2}{*}{ Southwest } & Tokyo-Nagoya & 24.7 & 25.5 & 1.2 & 1.1 & 4.5 & 4.4 & 69.6 & 68.9 & $27,915.1$ & $30,333.7$ \\
\hline & Expressway & 24.9 & 25.5 & 1.2 & 1.1 & 4.5 & 4.5 & 69.3 & 68.9 & $25,907.1$ & $28,105.9$ \\
\hline \multirow{2}{*}{\multicolumn{2}{|c|}{$\begin{array}{l}\text { Total for roads in the } \\
\text { Tokyo 23-ward area }\end{array}$}} & 35.8 & 35.5 & 2.4 & 2.4 & 12.2 & 12.4 & 49.6 & 49.7 & 33,374,492.9 & 31,197,133.8 \\
\hline & & 35.8 & 35.5 & 2.4 & 2.4 & 12.2 & 12.4 & 49.6 & 49.7 & $30,939,244.8$ & 28,921,064.8 \\
\hline
\end{tabular}

The greatest characteristic of vehicles by model was that artificial exhaust heat volume for cars and regular trucks on all roads was high on both weekdays and holidays, during the day and at night. If these values are amalgamated, they account for more than $80 \%$ of artificial exhaust heat volume for each road. Artificial exhaust heat volume was high on weekdays for all roads excluding those in central and south-western areas in the weekday/holiday category, and it was high in the daytime for all roads in the daytime/night-time category. Metropolitan Expressway No. 5 (Ikebukuro) in the northern area in particular had higher disparity between daytime and night-time on holidays than other roads.

Additionally, using initial functions, artificial exhaust heat volume in FY1999 in addition to FY2005 for moving targets was calculated to understand the past secular changes. Figure 6 shows the differences of artificial exhaust heat volume between FY1999 and FY2005. From Figure 6, for the past years, it is evident that artificial exhaust heat volume has decreased on the almost all roads, and such a tendency was especially remarkable on the Metropolitan Expressway No. 4 (Shinjuku), the Metropolitan Expressway (coastal route), and the Major Regional Roads No. 316 and No. 318 on weekdays, and the Metropolitan Expressway No. 3 on holidays. On the other hand, artificial exhaust heat volume has increased more on the roads originally with much quantity of artificial exhaust heat, as shown in Table 6 and Figure 4. 

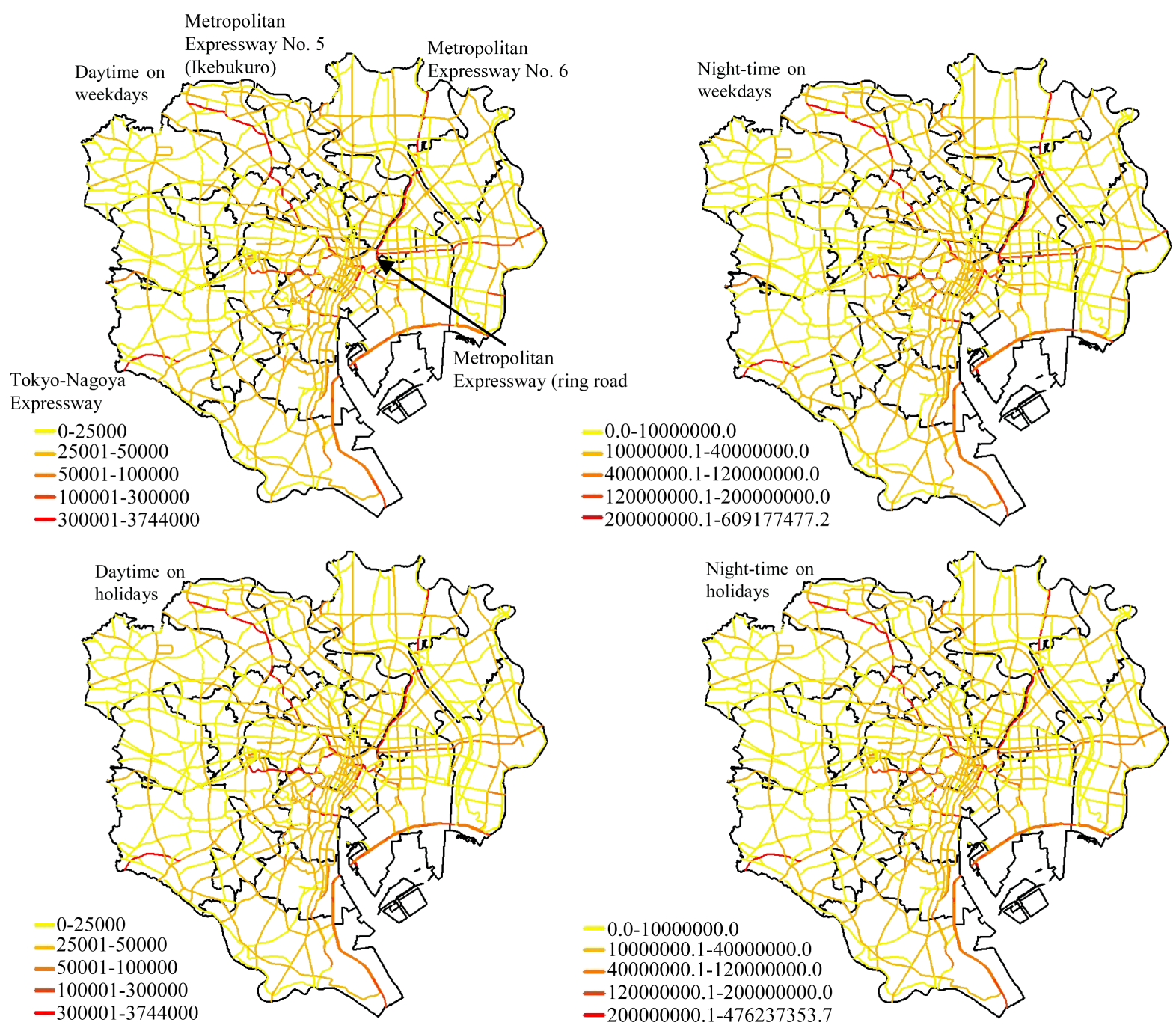

Figure 4. Statuses of artificial exhaust heat volume for moving targets (kJ, total of all vehicles).
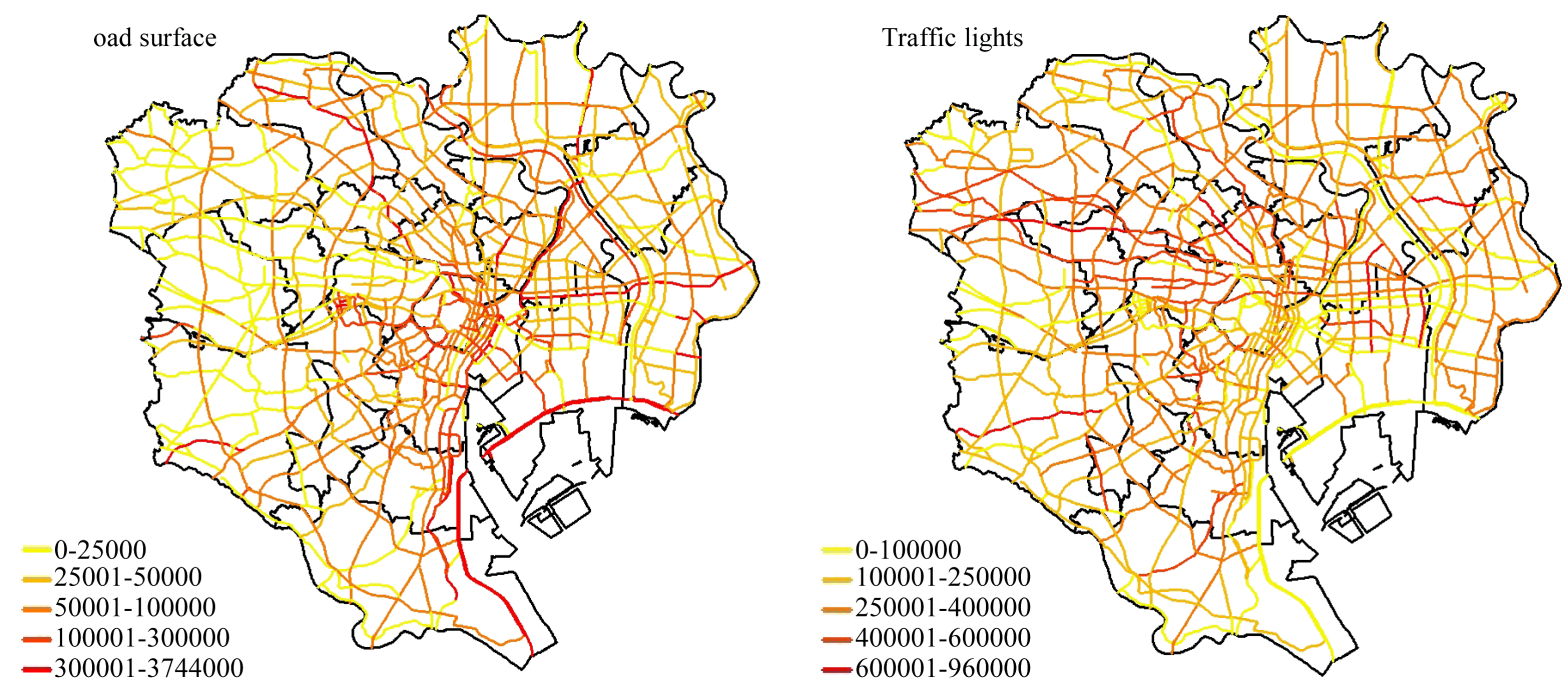

Figure 5. Status of artificial exhaust heat volume for stationary targets (kJ, total of all vehicles). 


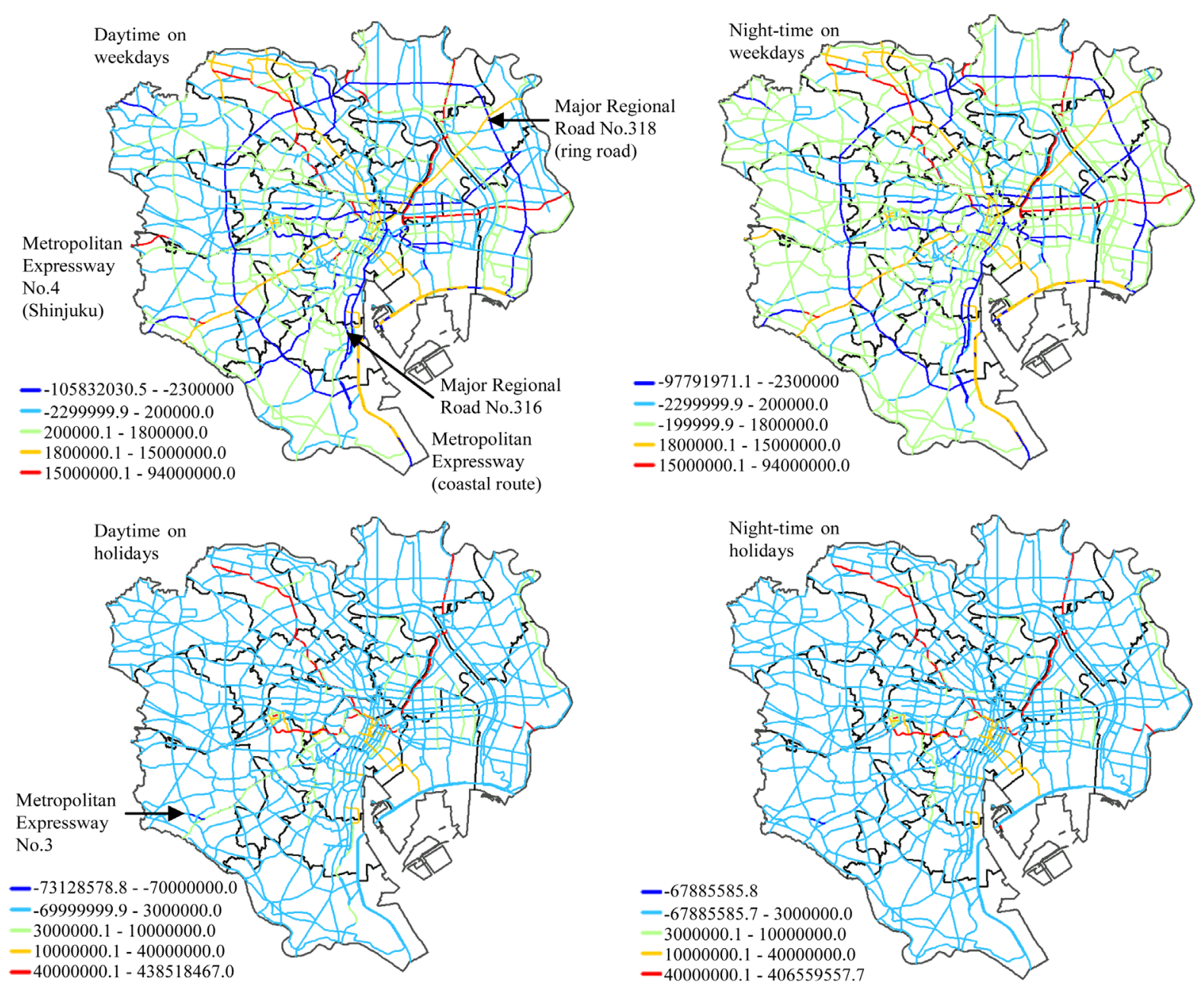

Figure 6. Differences of artificial exhaust heat volume between FY1999 and FY2005.

\section{Evaluation of UHI-Related Policy}

\subsection{Evaluation of UHI-Related Policy for Moving Targets}

A comparison was made between artificial exhaust heat volume after the implementation of policies using effect functions in UHI-related policies No. 1, 2, 3, 4, 5, 8 and 9 for moving targets, and artificial exhaust heat volume before the implementation of policies using initial functions and related policies were evaluated. Table 7 shows the proportion of reduction of artificial exhaust heat volume after the implementation of UHI-related policy for roads with high artificial exhaust heat volume in the same way as Table 6. Figures 7-10 show the evaluation results of UHI-related policies for moving targets, classifying into daytime and night-time in addition to weekdays and holidays.

It was understood that, for the Tokyo Ward Area overall, the reduction ratio of No. 2 (suppression of waste heat through choice of fuel burned) was high at over $10 \%$, and that it was possible to reduce artificial exhaust heat volume, albeit slightly, in No. 3 (improvement of traffic flow by securing space for cyclists and pedestrians), No. 4 (development of bypasses), and No. 8 (upgrading signal control). In addition, in No. 2, apart from Metropolitan Expressway No. 5 (Ikebukuro), the reduction ratios on weekdays and holidays were of a similar level, and it can be said that the effect of implementation was higher during the day in particular. However, after the implementation of No. 1 (spread of low-emission vehicles), it was suggested that there is potential for an increase in artificial exhaust heat volume mainly at night. As shown in the previous section, this is because waste heat coefficients by model and speed differ between day and night, and values are set to increase according to improvements in running speed. 


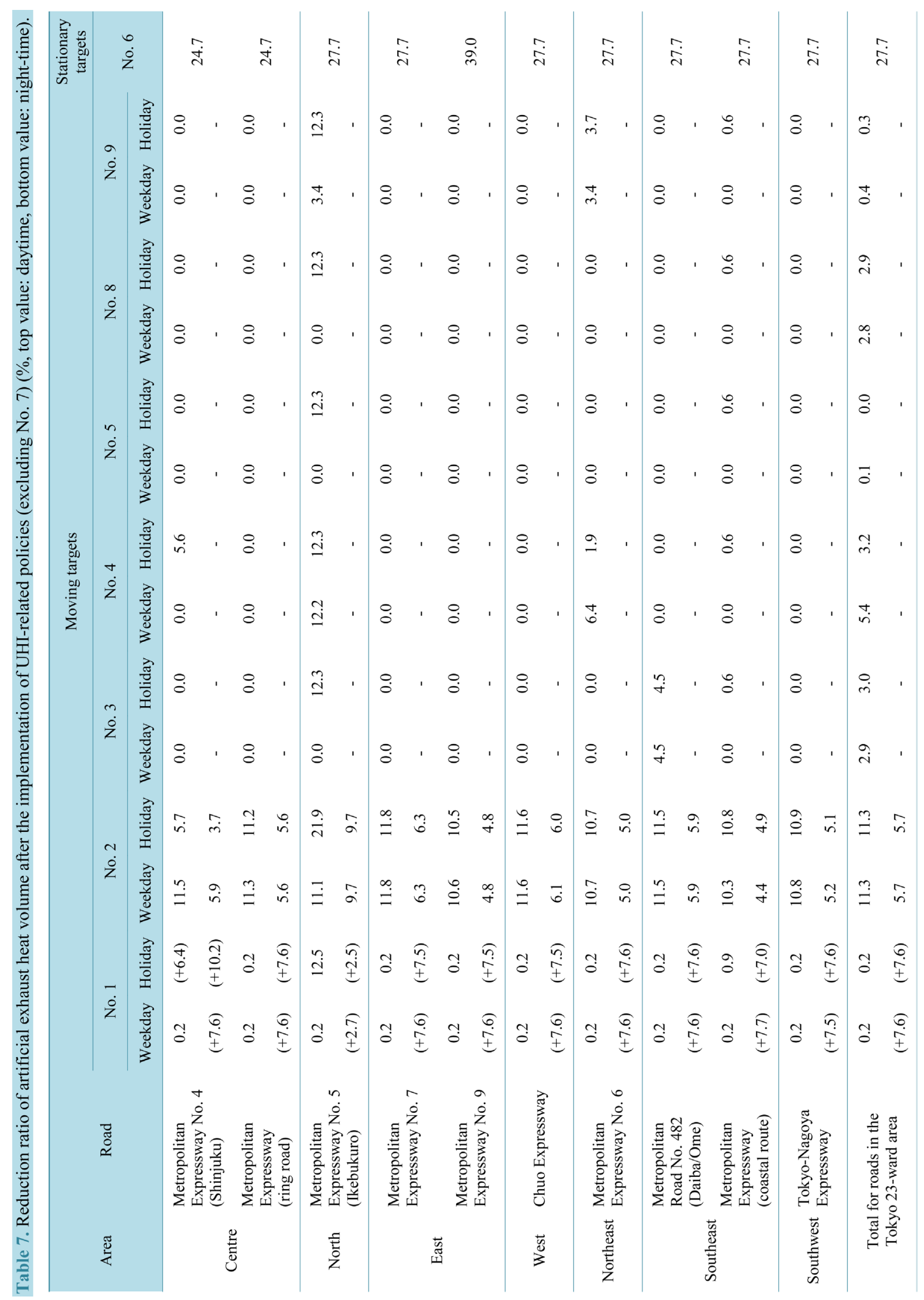



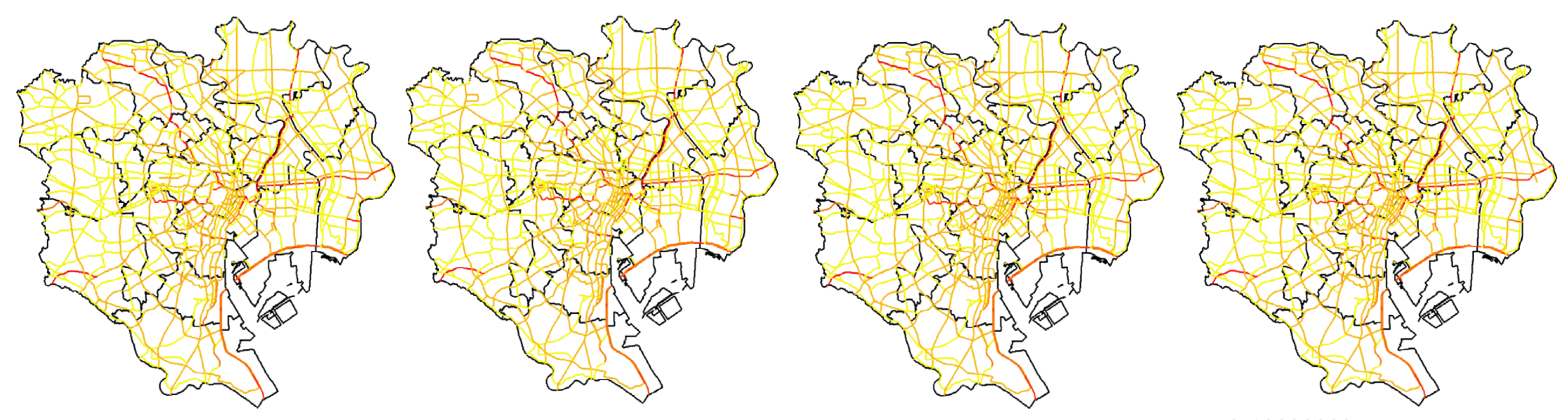

$=0.0-10000000.0$
$-10000000.1-40000000.0$
$-40000000.1-120000000.0$
$-120000000.1-200000000.0$
$-200000000.1-657184217.2$
Before implementation

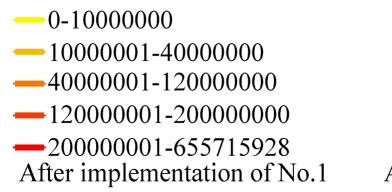

$-0-10000000$

$-10000001-40000000$

$-40000001-120000000$

$-120000001-200000000$

-200000001-584119083

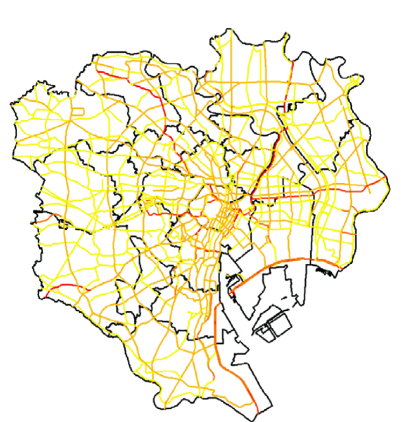

After implementation of No.

After implementation of No.2

$$
\begin{aligned}
& =0-10000000 \\
& =10000001-40000000 \\
& =40000001-120000000 \\
& =120000001-200000000 \\
& -200000001-657184217
\end{aligned}
$$

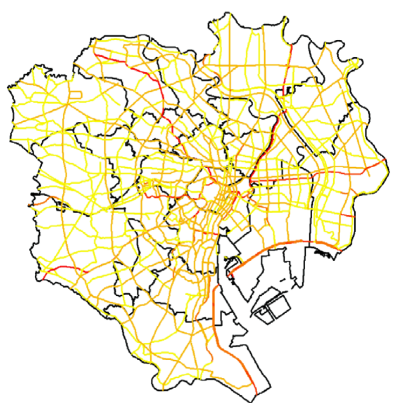

- 0-10000000

$-10000001-40000000$

- 40000001-120000000

- 120000001-200000000

-200000001-657184217

After implementation of No.5
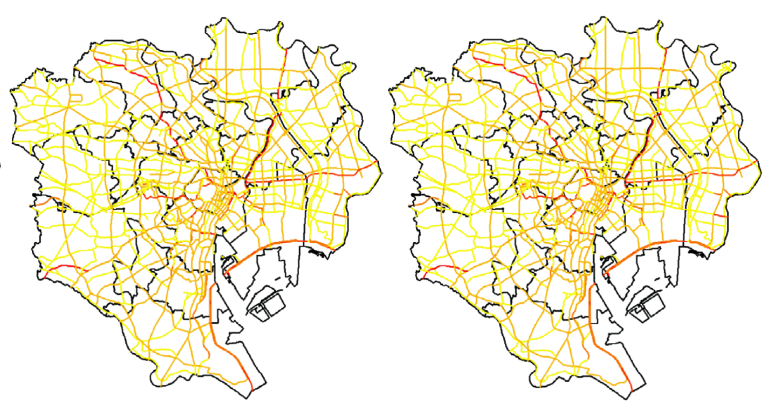

$-10000001-40000000$

-40000001-120000000

- 120000001-200000000

-200000001-576883050

After implementation of No.4

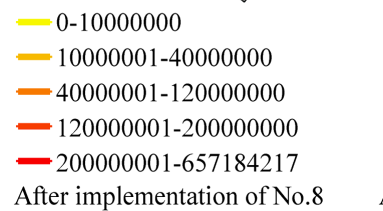

- 0-10000000

$-10000001-40000000$

-40000001-120000000

- 120000001-200000000

-200000001-635066179

After implementation of No.8

After implementation of No.9

Figure 7. Evaluation of UHI-related policies for moving targets in daytime on weekdays (kJ, total of all vehicles).

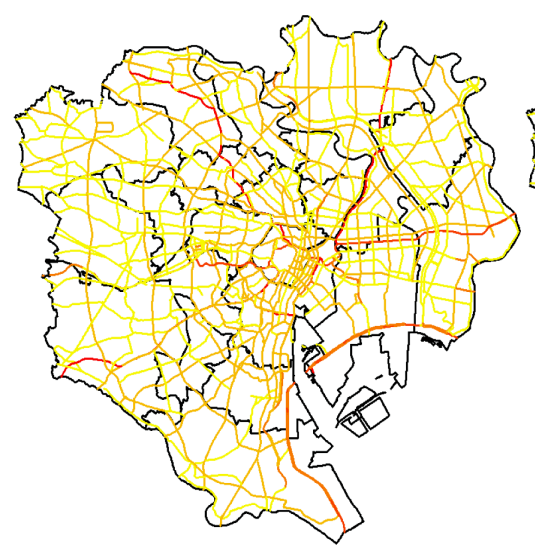

$-0.0-10000000.0$

$-10000000.1-40000000.0$

$-40000000.1-120000000.0$

$-120000000.1-200000000.0$

- 200000000.1-609177477.2

Before implementation

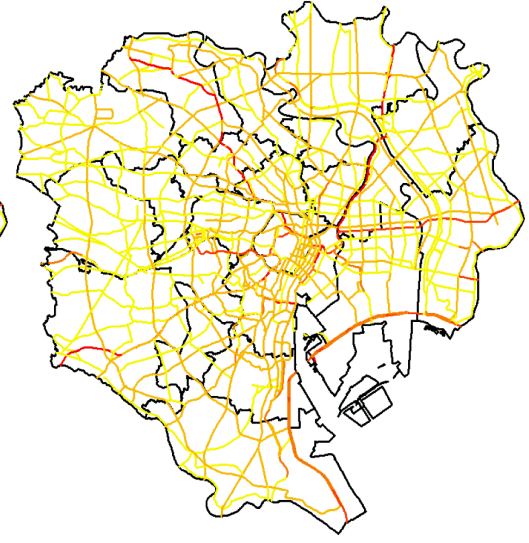

-0-10000000

$-10000001-40000000$

-40000001-120000000

- 120000001-200000000

-200000001-655437328

After implementation of No.1

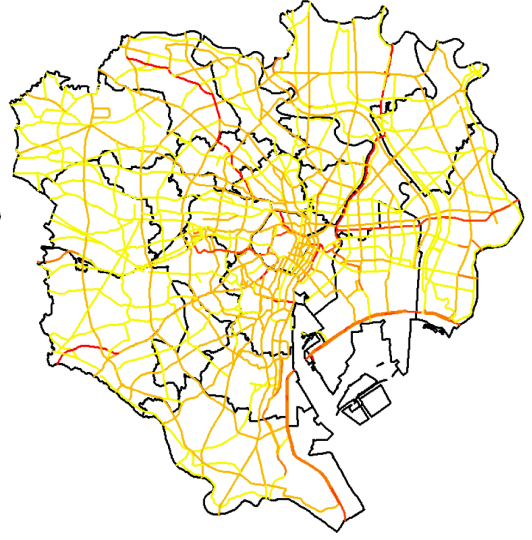

- 0-10000000

$-10000001-40000000$

-40000001-120000000

- 120000001-200000000

-200000001-576030017

After implementation of No.2

Figure 8. Evaluation of UHI-related policies for moving targets in night-time on weekdays (kJ, total of all vehicles). 

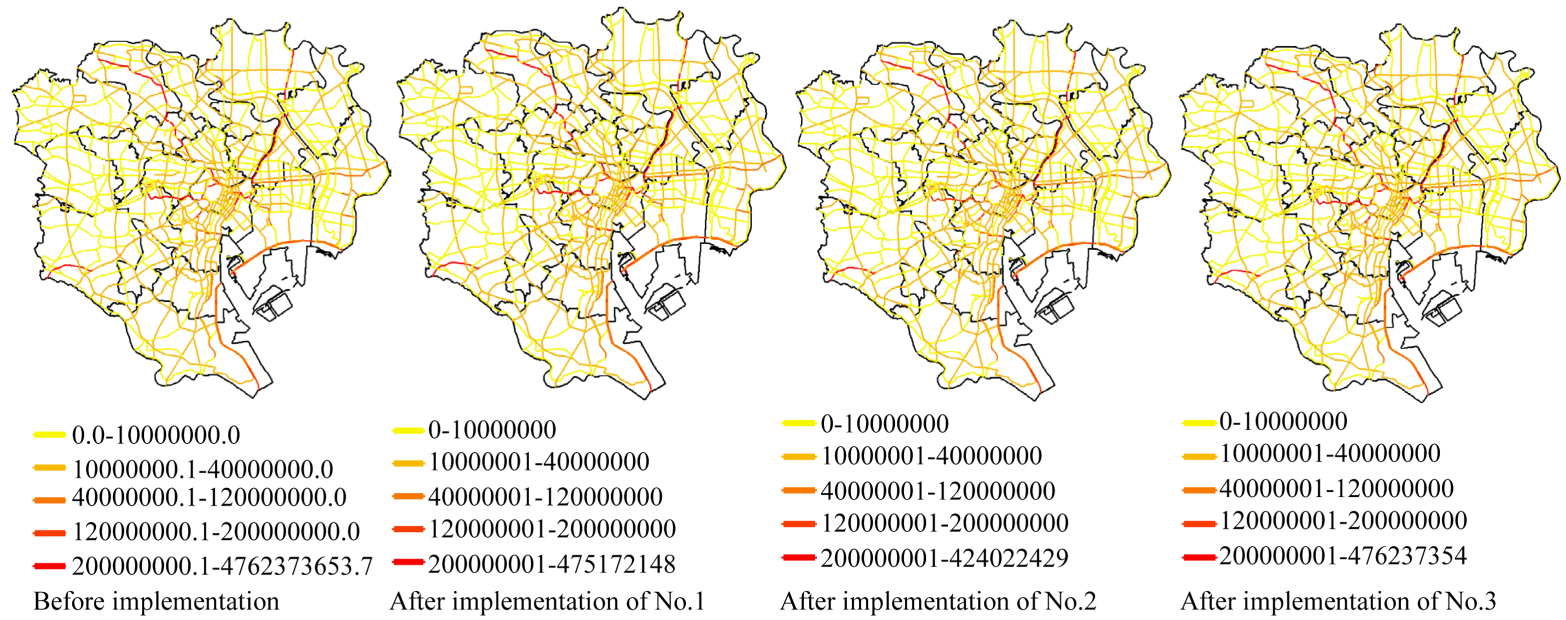

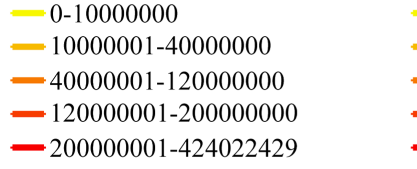

After implementation of No.2

\section{0-10000000 \\ $-10000001-40000000$ \\ -40000001-120000000 \\ -120000001-200000000 \\ -200000001-476237354}

After implementation of No.3

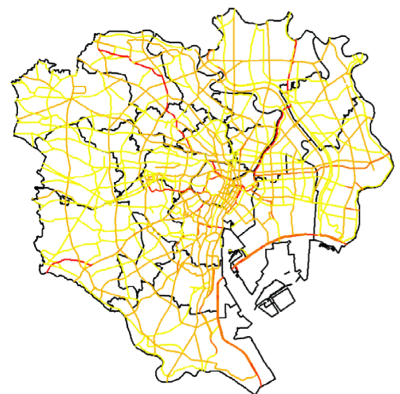

- 0-10000000

-10000001-40000000

$-40000001-120000000$

-120000001-200000000

-200000001-476237354

After implementation of No.4

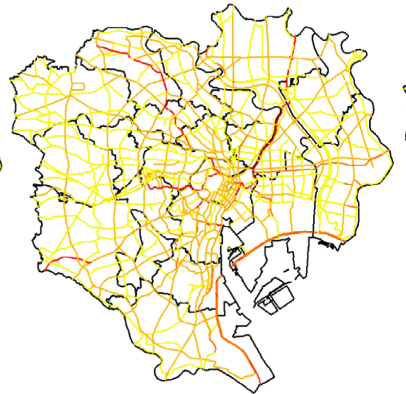

- 0-10000000

\section{$=10000001-40000000$}

$-40000001-120000000$

-120000001-200000000

-200000001-476237354

After implementation of No.5

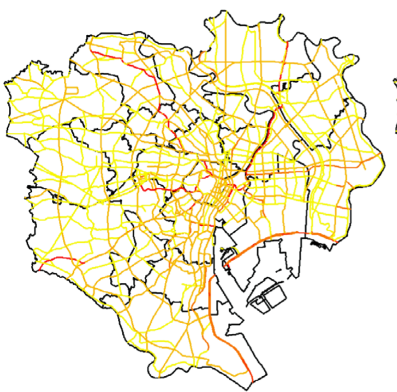

0-10000000

- 10000001-40000000

-40000001-120000000

- 120000001-200000000

-200000001-476237354

After implementation of No.8

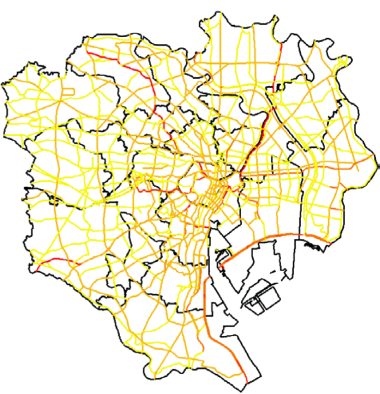

- $0-10000000$

-10000001-40000000

-40000001-120000000

- 120000001-200000000

—200000001-476237354

After implementation of No.9

Figure 9. Evaluation of UHI-related policies for moving targets in daytime on holydays (kJ, total of all vehicles).

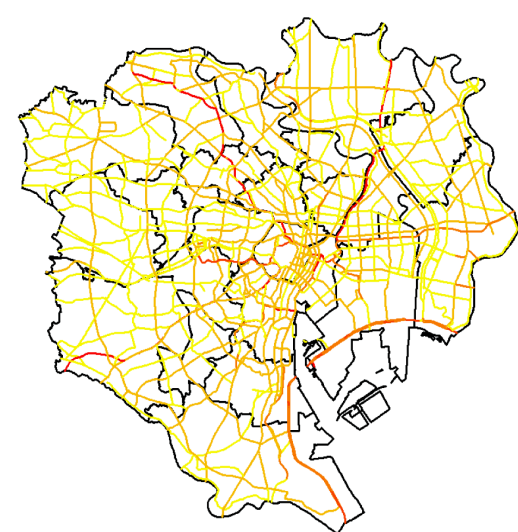

$=0.0-10000000.0$

$-10000000.1-40000000.0$

$-40000000.1-120000000.0$

$-120000000.1-200000000.0$

-200000000.1-441402151.0

Before implementation

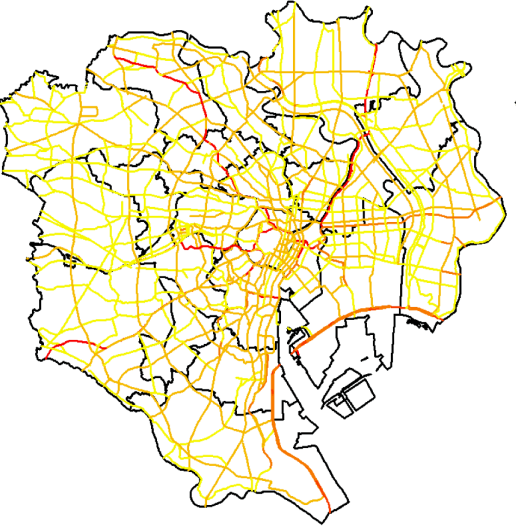

- 0-10000000

$-10000001-40000000$

-40000001-120000000

- 120000001-200000000

—200000001-474971074

After implementation of No.1

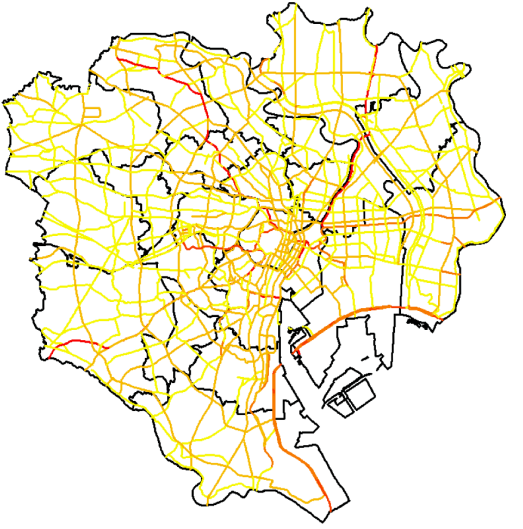

- 0-10000000

$-10000001-40000000$

-40000001-120000000

$-120000001-200000000$

-200000001-418227063

After implementation of No.2

Figure 10. Evaluation of UHI-related policies for moving targets in night-time on holidays (kJ, total of all vehicles). 
Meanwhile, it was discovered that roads with high reduction ratios for artificial exhaust heat volume differed for each UHI-related policy. For example, though the above-mentioned No. 1, No. 5 (improvement of access roads to airports and ports), and No. 9 (diffusion of ETC) did not manage to reduce artificial exhaust heat volume much in the Tokyo Ward Area overall, the Metropolitan Expressway No. 5 (Ikebukuro) has a reduction ratio of more than $10 \%$ during the day on holidays.

\subsection{Evaluation of UHI-Related Policy for Stationary Targets}

In the same way as in the previous section, evaluation of UHI-related policies No. 6 and 7 for stationary targets was conducted. Artificial exhaust heat volume reduction ratio for No. 6 (special road surfaces) is shown in Table 7 above, and the reduction ratio for roads with high artificial exhaust heat volume among those installed with traffic signals for No. 7 (increase in efficiency of energy consumption equipment) is shown in Table 8. Figure 11 and Figure 12 show the evaluation results of UHI-related policies for stationary targets. Though differences in reduction ratios were observed for each road as shown in Table 7 and Table 8, as discrepancies in road width in No. 6 and number of traffic signals by unit length in No. 7 were reflected, differences occurred.

Table 8. Reduction ratio of artificial exhaust heat volume after the implementation of UHI-related policy No. 7 (\%).

\begin{tabular}{|c|c|c|}
\hline Area & Road & No. 7 \\
\hline Centre & Major Regional Road No. 302 (Shinjuku/Ryogoku) & 30.9 \\
\hline North & Metropolitan Road No. 455 (Hongo/Akabane) & 30.9 \\
\hline \multirow{2}{*}{ East } & Metropolitan Road No. 465 & 30.9 \\
\hline & Metropolitan Road No. 474 & 30.9 \\
\hline West & Major Regional Road No. 3 (Setagaya/Machida) & 30.9 \\
\hline Northwest & Major Regional Road No. 9 (Ichikawa/Yotsugi) & 31.5 \\
\hline Southeast & Metropolitan Road No. 482 (Daiba/Ome) & 30.9 \\
\hline Southwest & Major Regional Road No. 426 (Kamiuma/Okusawa) & 30.9 \\
\hline & Total for roads in the 23 Wards of Tokyo & 30.9 \\
\hline
\end{tabular}

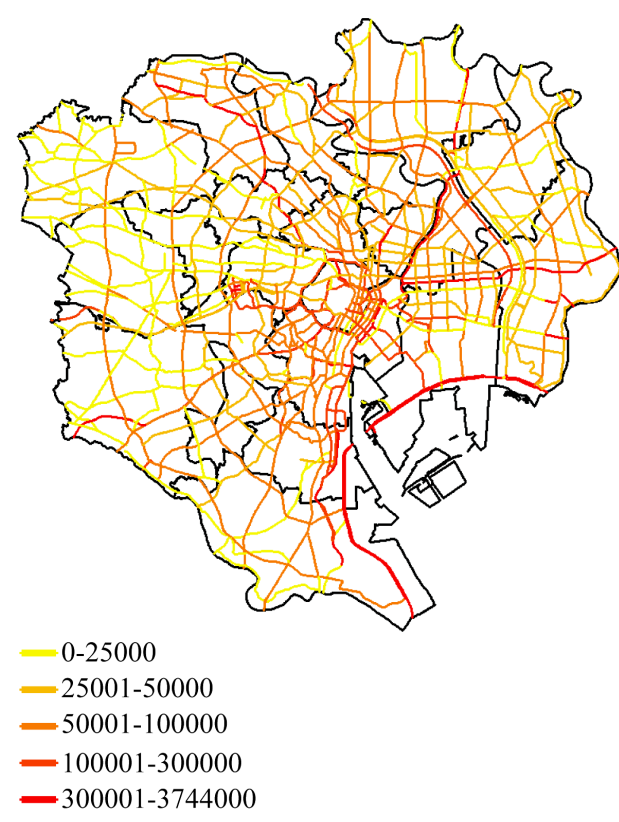

Before implementation

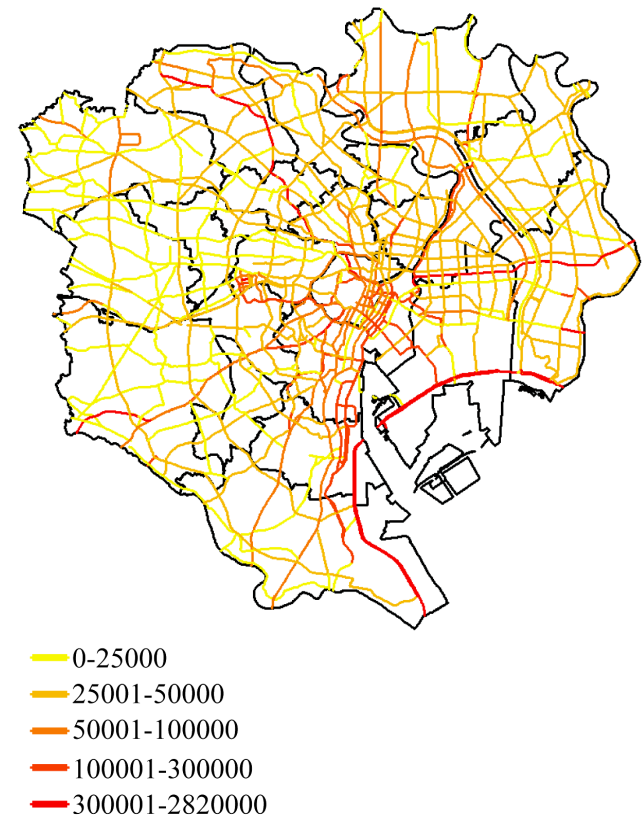

After implementation of No.6

Figure 11. Evaluation of UHI-related policy for stationary targets (No. 6, kJ). 


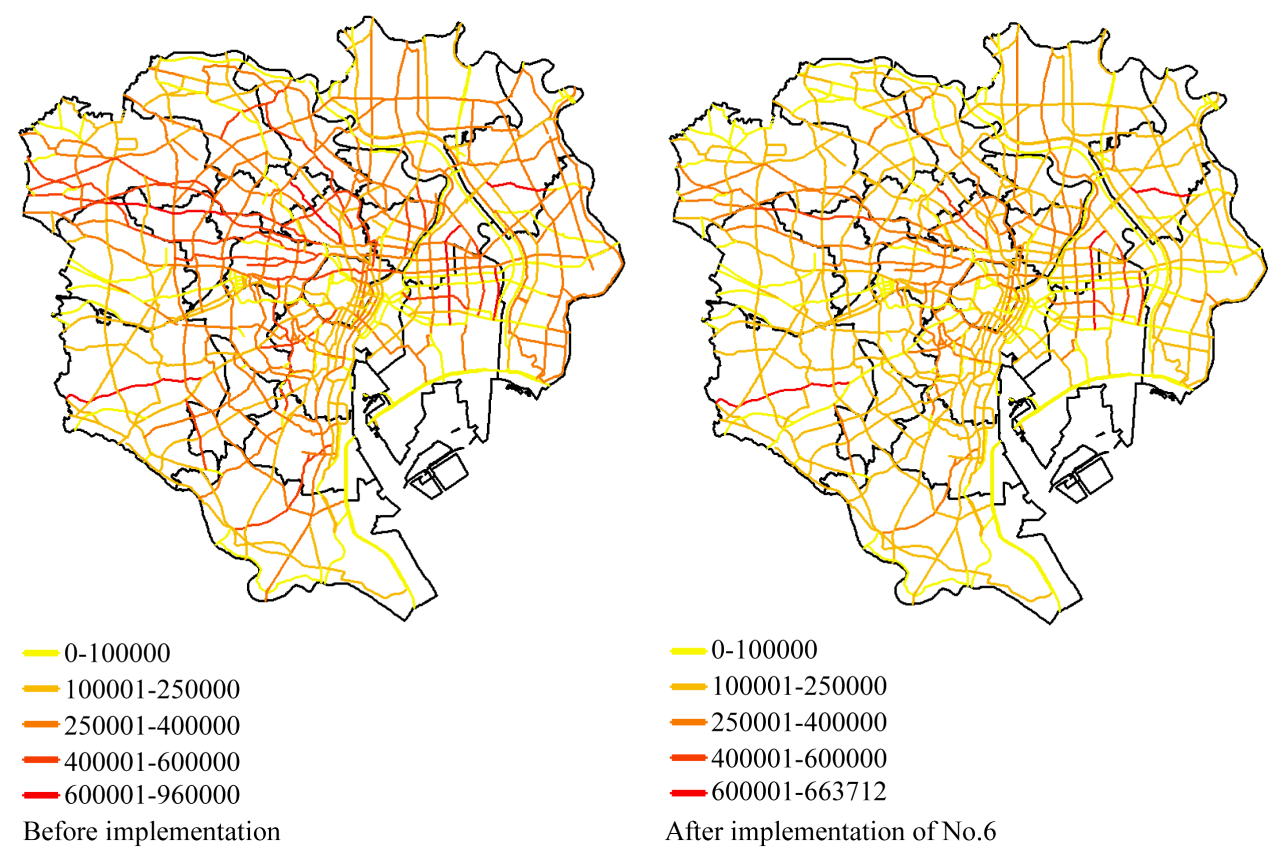

Figure 12. Evaluation of UHI-related policy for stationary targets (No. 7, kJ).

By implementing these two related policies, it was discovered that it was possible to reduce artificial exhaust heat volume in the Tokyo Ward Area overall by $27.7 \%$ and $30.9 \%$ respectively, and that it was possible to obtain the same level of effects in all areas. Consequently, as shown in Section 5.2, though artificial exhaust heat volume for stationary targets was remarkably lower than that of moving targets, it can be said that reduction ratio was higher than that of moving targets in this related policy. As the two policies mentioned above are implemented in all Tokyo Ward Area, it is expected that artificial exhaust heat volume will reduce over a wide area.

However, as policy No. 7 targets roads installed with traffic signals, implementation effects were not obtained on expressways or ring roads with high artificial exhaust heat volume for moving targets as shown in the previous section. In addition, though this study does not target small-scale roads that are not published in the road traffic census, as it is thought to be possible to expect implementation effects for these with policy No. 7, it is necessary to develop a more detailed road traffic status database and conduct evaluation.

\section{Conclusions and Future Research Topics}

By using GIS as a database development and information analysis tool in this study, it was possible to develop a digital map database that reflects road traffic status, and to calculate artificial exhaust heat volume for road traffic in each road unit. Specific evaluation of UHI-related policies was then conducted, and artificial exhaust heat volume was able to be explained and displayed in an easy-to-understand manner on a digital map with spatial distribution status.

The conclusions of this study can be summarized by the following three points.

1) Artificial exhaust heat volume for moving targets was remarkably higher than that of stationary targets, and, in particular, artificial exhaust heat volume was high on roads with remarkable numbers of vehicles and running speeds such as expressways and ring roads. Artificial exhaust heat volume was particularly high for cars and regular trucks by model and for weekdays and holidays, and daytime and night-time, artificial exhaust heat volume was mainly high during the day on weekdays.

2) In UHI-related policy for moving targets, the suppression of waste heat through choice of fuel burned, improvement of traffic flow by securing space for cyclists and pedestrians, development of bypasses and upgrading signal control managed to reduce artificial exhaust heat volume, even though there were differences in degree of reduction. However, roads with high artificial exhaust heat volume reduction ratio differed with each UHIrelated policy. 
3) In UHI-related policy for stationary targets, special road surfaces, and the increase in efficiency of energy consumption equipment achieved a reduction ratio of around 30\% in artificial exhaust heat volume, more than moving targets as well as making it possible to expect a reduction in artificial exhaust heat volume on a wide scale.

Examples of future research themes are to apply the evaluation methods in this study to other mega cities in the world with high UHI density and evaluation.

\section{References}

[1] Ministry of Economy, Trade and Industry (2007) Energy 2007 of Japan. 6 p.

[2] Ministry of Environment (2003) Field Survey Report on the Environmental Influence by Heat Island Effect. 10 p.

[3] Mikami, T. (2005) Urban Heat Island Phenomena and Their Causing Factors: A Case Study of Tokyo Metropolis. Journal of Geography, 114, 496-506. http://dx.doi.org/10.5026/jgeography.114.3_496

[4] Meteorological Agency (2007) Monitoring Report on Heat Island Effect (FY 2006 Summer-Kanto and Kinki Regions). http://www.data.jma.go.jp/cpdinfo/himr/2006/himr2006.pdf

[5] Hirano, Y., Yasuoka, Y. and Ichinose, T. (2004) Evaluation of Effect of Vegetation on Urban Heat Island by Using Satellite Remote Sensing Data and Mesoscale Meteorological Model. Environmental Science, 17, 343-358.

[6] Hoyano, A. (2005) Measures against Heat Island, and Estimation and Evaluation of the Effects: Focusing on Urban Development. Transactions of the Society of Heating. Transaction of the Society of Heating, Air-Conditioning and Sanitary Engineers of Japan, 79, 37-43.

[7] The GIS Used in This Study Was ESRI’s Arc GIS Desktop Arc Info (Ver. 9.2).

[8] Tyson, P.D. and Preston-Whyte, R.A. (1973) Temperature Structure of City Sky: Paper Review and Survey Plan of Urban Heat Island Effect in Johannesburg. Journal of Architecture and Building Science, 1062, 258-259.

[9] Mikami, T. (2002) Solution Proposed by the Cooperation of Various Academic Fields: Artificial Exhaust Heat and Changes in Urban Areas to Produce Warming. Energy Review, 22, 6-9.

[10] Ashie, Y., Lee, H. and Yoon, S. (2004) Analysis of Exhaustion Characteristics of Anthropogenic Exhaustion Heat Considering the Differences of Sensible and Latent Heat in Tokyo 23 Wards. Transactions of the Society of Heating. Transaction of the Society of Heating, Air-Conditioning and Sanitary Engineers of Japan, 92, 121-130.

[11] Ishimaru, Y. (2004) Survey of the Artificial Exhaust Heat in Heat Island Effect. Environmental Information Science, 33, 84-86.

[12] Ichinose, T. (2009) Mitigation of Urban Climate and Its Feedback to Carbon Emission. Environmental Science, 22, 301-308.

[13] Terui, N., Narumi, D., Shimoda, Y. and Mizuno, M. (2009) Study on the Analysis of the Cause of an Urban Heat Island Phenomenon through Reproducing the Past Condition. Journal of Environmental Engineering, 74, 1163-1172. http://dx.doi.org/10.3130/aije.74.1163

[14] Mochida, A. and Watanabe, H. (2001) Effects of Artificial Heat Release on Urban Heat Island: Comparison between Urban Climate in the Edo Era and the Present. Energy and Resources, 22, 30-35.

[15] Narumi, D., Otani, F., Kondo, A., Shimoda, Y. and Mizuno, M. (2002) Effect of Anthropogenic Waste Heat upon Urban Thermal Environment: Analyses of Countermeasures for Mitigating Heat Islands Phenomena Using a Numerical Model Part 1. Journal of Architecture, Planning and Environmental Engineering, 562, 97-104.

[16] Yoshida, S., Ooka, R., Murakami, S. and Harayama, K. (2002) The Effects of Artificial Heat Release on Urban Heat Island Using CFD Analysis. Memoirs of the Faculty of Engineering, Fukui University, 50, 7-11.

[17] Yoshida, S., Ooka, R., Murakami, S. and Harayama, K. (2002) Effects of Artificial Heat Release on Heat Island Phenomena in Tokyo Area Using CFD Analysis. Monthly Journal of the Institute of Industrial Science, University of Tokyo, 54, 79-83.

[18] Kannari, A., Mikami, T. and Izumi, T. (2004) Direct Effects on Temperature Rise by Anthropogenic Heat Emissions into the Metropolitan Urban Atmosphere. Journal of Geography, 113, 802-815. http://dx.doi.org/10.5026/jgeography.113.6_802

[19] Sugawara, H., Wook, J.D. and Tomine, K. (2005) Re-Examination of City Air Temperature for Heat Island Intensity Evaluation: Case Study in Seoul, Korea. Tenki, 52, 29-38.

[20] Tamura, H., Hiraguchi, H. and Iwatsubo, T. (2006) Development of Prediction Method for Urban Heat Environment Influenced by Large-Scale Wind. CRIEPI Research Report, N05032, 20 p.

[21] Narumi, D. (2006) Effects of Anthropogenic Waste Heat upon Urban Thermal Environment in Cities. Environmental Conservation Engineering, 35, 485-490. http://dx.doi.org/10.5956/jriet.35.485 
[22] Ooka, R., Chen, H., Hong, H. and Nakashima, M. (2006) Study on Impact Factor Index of Buildings on Outdoor Thermal Environment Using Coupled Simulation of Convection, Radiation and Conduction. Proceedings of National Symposium on Window Engineering, 19, 91-96.

[23] Shiraki, Y., Kondo, A. and Ichinose, T. (2007) The Impact of Surface Form on Urban Temperature Using Remote Sensing and GIS. Environmental Science, 20, 347-358.

[24] Shiraki, Y., Higuchi, A. and Kondo, A. (2009) The Effect of an Urban Environment on the Precipitation in Areas around Tokyo. Environmental Science, 22, 187-195.

[25] Narumi, D., Habara, K. and Mizuno, M. (2009) Development of an Environmental Thermal Load Evaluation System for the Purpose of Mitigating Urban Thermal Environment: Part2-Framework of the Weighted Heat Flux Evaluation Method and Example of Evaluation at Building Level. Transaction of the Society of Heating, Air-Conditioning and Sanitary Engineers of Japan, No. 147, 17-28.

[26] Ota, M. (2001) Artificial Exhaust Heat and the Control Measures. Green Handbook, No. 57, 49-57.

[27] Tamura, H., Urabe, W. and Hiroguchi, H. (2003) Development of Interactive Prediction Method between Heat Environment in a Block of Urban Area and Cooling Load in a Building: Evaluation for Introducing Heat Environment Mitigation System. CRIEPI Research Report, U02025, 18 p.

[28] Tamura, H. and Hiroguchi, H. (2005) Development of Interactive Prediction Method between Heat Environment in a Block of Urban Area and Cooling Load in a Building (No. 2): Improvement of Model for Estimating Effect of Roof Greening. CRIEPI Research Report, N04016, 19 p.

[29] Tamura, H., Ishii, K., Yokoyama, H., Iwatsubo, T., Hiraguchi, H., Ando, H., Yamaguchi, T., Ichino, M., Akiyama, Y. and Mikami, H. (2005) Numerical Prediction of Heat Island Mitigation Effect in Tokyo. FY 2005 Annals of Tokyo Metropolitan Research Institute for Environmental Protection, 10-18.

[30] Tamura, H., Ishii, K., Yokoyama, H., Iwatsubo, T., Hiraguchi, H., Ando, H., Yamaguchi, T., Mikami, H., Ichino, M. and Akiyama, Y. (2006) Prediction of Heat Island Mitigation Effect in Tokyo by Three Dimensional Numerical Simulation. CRIEPI Research Report, N05032, 40 p.

[31] Oba, T., Yoshida, T., Mochida, A., Yoshino, H. and Watanabe, H. (2006) Zoning of the Urban Climate in Sendai for Selecting the Appropriate Countermeasure as against Urban Heat Island Effects. Proceedings of National Symposium on Window Engineering, 19, 55-60.

[32] Kawamoto, Y. and Ooka, R. (2008) Improvement of Parameterization of Ground Surface and Incorporation of Anthropogenic Heat Release: Development of Urban Climate Analysis Model Using MM5 Part 1. Journal of Environmental Engineering (Transactions of AIJ), 73, 1125-1132. http://dx.doi.org/10.3130/aije.73.1125

[33] Tokyo Metropolitan Heat Island Mitigation Committee (2003) Heat Island Measures Action Policy: For Realization of Environmental City Tokyo. 43 p.

[34] Geographical Survey Institute [Issued 2003 (6 Issues)], Numerical Map 2500 (National Geospatial Framework) Kanto3.

[35] Japan Society of Traffic Engineers (2007) 2005 Road Traffic Census National Road/Street Traffic Status Survey.

[36] Ministry of Environment (2003) Survey and Examination of the Environmental Influence by Heat Island Effect (FY 2003). http://www.env.go.jp/air/report/h16-04/index.html

[37] Ministry of Land, Infrastructure, Transport and Tourism (2007) Measures against Heat Island Effect. http://www.mlit.go.jp/sogoseisaku/environment/sosei_environment_mn_000016.html

[38] Ministry of Land, Infrastructure, Transport and Tourism/Ministry of the Environment (2004) Survey of Heat Island Mitigation through Artificial Exhaust Heat Control in Urban Areas 2003. http://www.env.go.jp/air/report/h16-05/index.html

[39] Kanto Regional Development Bureau, Ministry of Land, Infrastructure, Transport and Tourism (2004) The Challenge of Alleviating the Heat Island Phenomenon on Roads-Results of the Tokyo Environmental Surface Project (Press Conference Documents, May 25, 2004).

[40] National Police Agency (2002) Conversion of Traffic Signals to LED. https://www.npa.go.jp/koutsuu/kisei/institut/kazu.pdf 